\title{
The nose of the sperm whale: overviews of functional design, structural homologies and evolution
}

\author{
STEFAN HUGGENBERGER ${ }^{1,2}$, MICHEL ANDRÉ ${ }^{3}$ AND HELMUT H. A. OELSCHLÄGER ${ }^{4}$ \\ ${ }^{1}$ Biocentre, University of Cologne, 50923 Cologne, Germany, ${ }^{2}$ Department of Anatomy II, University of Cologne, 50924 Cologne, \\ Germany, ${ }^{3}$ Laboratori d'Aplicacions Bioacústiques, Universitat Politècnica de Catalunya, Centre Tecnològic de Vilanova i la Geltrú, \\ Avenida.Rambla Exposició, s/n, 08800 Vilanova i la Geltrú, Barcelona, Spain, ${ }^{4}$ Department of Anatomy III (Dr Senckenbergische \\ Anatomie), Johann Wolfgang Goethe University of Frankfurt am Main, 60590 Frankfurt am Main, Germany
}

\begin{abstract}
The hypertrophic and much elongated epicranial (nasal) complex of sperm whales (Physeter macrocephalus) is a unique device to increase directionality and source levels of echolocation clicks in aquatic environments. The size and shape of the nasal fat bodies as well as the peculiar organization of the air sac system in the nasal sound generator of sperm whales are in favour of this proposed specialized acoustic function. The morphology of the sperm whale nose, including a 'connecting acoustic window' in the case and an anterior 'terminal acoustic window' at the rostroventral edge of the junk, supports the 'bent horn hypothesis' of sound emission. In contrast to the laryngeal mechanism described for dolphins and porpoises, sperm whales may drive the initial pulse generation process with air pressurized by nasal muscles associated with the right nasal passage (right nasal passage muscle, maxillonasolabialis muscle). This can be interpreted as an adaptation to deep-diving and high hydrostatic pressures constraining pneumatic phonation. Comparison of nasal structures in sperm whales and other toothed whales reveals that the existing air sac system as well as the fat bodies and the musculature have the same topographical relations and thus may be homologous in all toothed whales (Odontoceti). This implies that the nasal sound generating system evolved only once during toothed whale evolution and, more specifically, that the unique hypertrophied nasal complex was a main driving force in the evolution of the sperm whale taxon.
\end{abstract}

Keywords: Cetacea, epicranial complex, coda

Submitted 10 April 2014; accepted 6 July 2014

\section{INTRDDUCTION}

Toothed whales (Odontoceti) are unique in the morphology of their forehead (nasal complex), which houses a set of structures, mostly unknown in other mammals, building an epicranial complex. These structures are usually centred around the blowhole which moved from a subterminal position at the tip of the nose in ancient whales (Archeoceti) to the vertex of the head. After respiration, the second important function of the nasal complex in toothed whales is the generation and transmission of echolocation clicks and communication sounds (Norris \& Harvey, 1974; Cranford et al., 2000; Cranford \& Amundin, 2004; Au et al., 2006; Madsen et al., 2010). For sound generation, toothed whales have specific valves (monkey lips $=$ phonic lips) associated with small fat bodies (dorsal bursae $=$ bursae cantantes), which can vibrate in the air current and generate sound waves in adjacent tissues (Cranford, 1988; Cranford et al., 1996; Dubrovsky et al., 2004; Huggenberger et al., 2009). These sounds (i.e. echolocation clicks and short tonal sounds) are transmitted to another, much larger acoustic fat body (melon), which

Corresponding author:

S. Huggenberger

Email: st.huggenberger@uni-koeln.de focuses the sound beam prior to emission into the surrounding water (Norris \& Harvey, 1974; Au et al., 2006). As there are two respiratory nares (nasal passages) serving the blowhole area, each equipped with a set of air sacs and bursae cantantes, both sides, in principle, are independent from each other and, in many toothed whales, have specialized in different ways concerning functional properties and directional asymmetry (Cranford et al., 1996, 2000; Madsen et al., 2010).

Some of the most asymmetric and specialized foreheads are found in members of the superfamily Physeteroidea (Heyning \& Mead, 1990), which includes three extant species: the sperm whale (Physeter macrocephalus, Linnaeus, 1758) as well as the smaller dwarf sperm whale (Kogia sima, Blainville, 1838) and pygmy sperm whale (Kogia breviceps, Owen, 1866) (Rice, 1998). Male sperm whales may attain a total body length of nearly $20 \mathrm{~m}$ but females usually reach only half that size. Thus, sexual dimorphism is more pronounced here than in other toothed whales (Berzin, 1972; Cranford, 1999). The sperm whale head, similar to the bow of a submarine in shape, is extremely large in both absolute and relative terms. In the adult male, it may reach nearly one third of the total body length and its weight may equal more than one third of the total body weight (Nishiwaki et al., 1963). Hypertrophy of the nasal complex on the right side as well as the concomitant secondary forward projection of the blowhole with the nasal tracts have led to this uniquely enlarged 
and asymmetric nose (Klima et al., 1986a, b; Cranford et al., 1996; Cranford, 1999). Accordingly, the world's largest nose reduced the skull, and particularly the neurocranium, to an insignificant small structure (Klima, 1990). This singularity has led some authors to describe the sperm whale as 'a nose with an outboard motor' (Møhl et al., 2003b).

Initial descriptions of the sperm whale nose can be found as early as the end of the 19th century (Pouchet \& Beauregard, 1885; Raven \& Gregory, 1933; Schenkkan \& Purves, 1973). The most prominent structures in the nasal complex of sperm whales are two hypertrophied fat bodies: the junk seated on the bony rostrum of the skull and the spermaceti organ lying on top of the junk (Figures $1 \& 2$ ). The junk consists of connective tissue in which lens-like fat bodies are embedded (Figure 1). The 'lenses', referred to as wafers (Møhl, 2001), stand nearly perpendicular to the body axis of the animal. The whole set of lenses tapers backward along the dorsal surface of the rostrum of the skull in the direction of the bony nostrils (Figure 1).

The spermaceti organ is fusiform in shape and enclosed in a thick sheath of extremely tough connective tissue 'case' which only lacks caudally between the two fat bodies. Between the spermaceti organ and the junk the soft and smooth right nasal passage runs as a flattened sub-horizontal
A

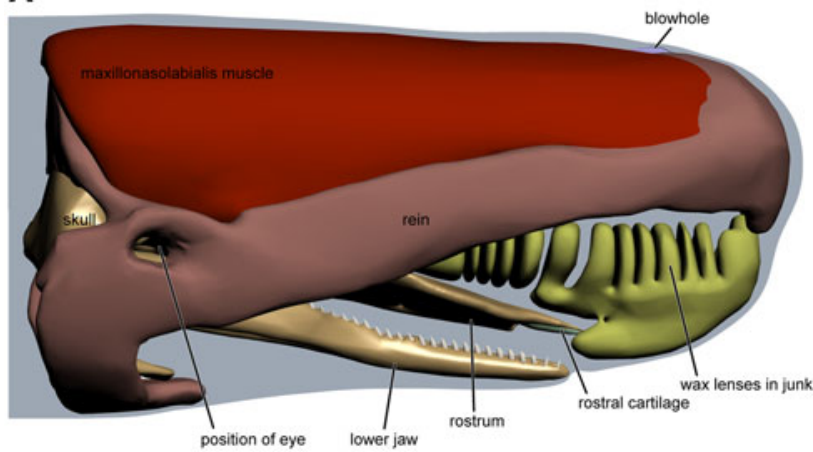

B cartilaginous nasal septum

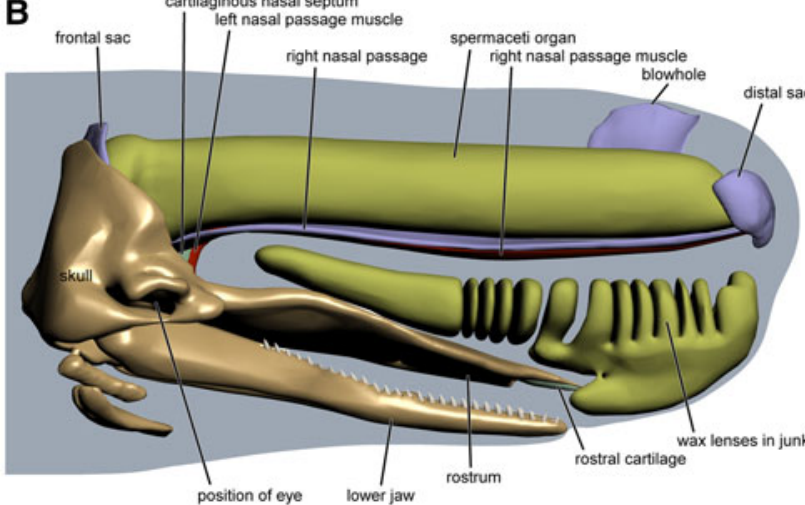

C

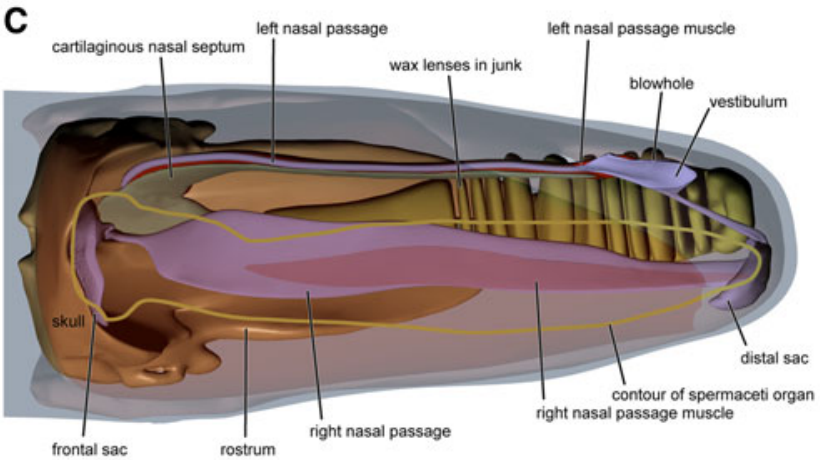

D

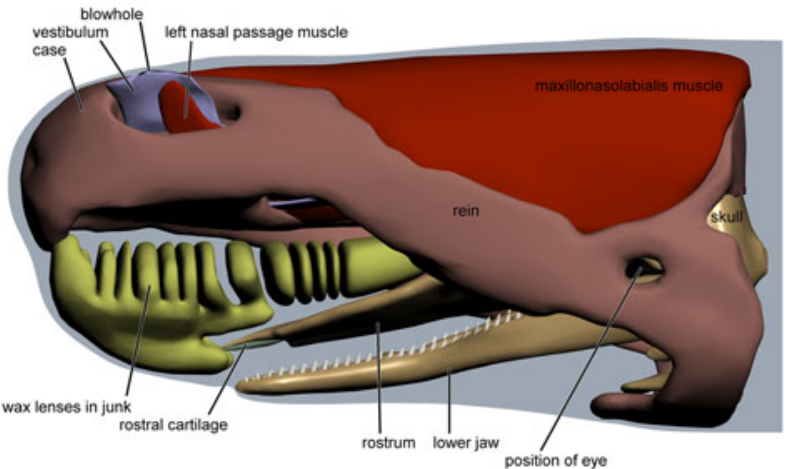

E
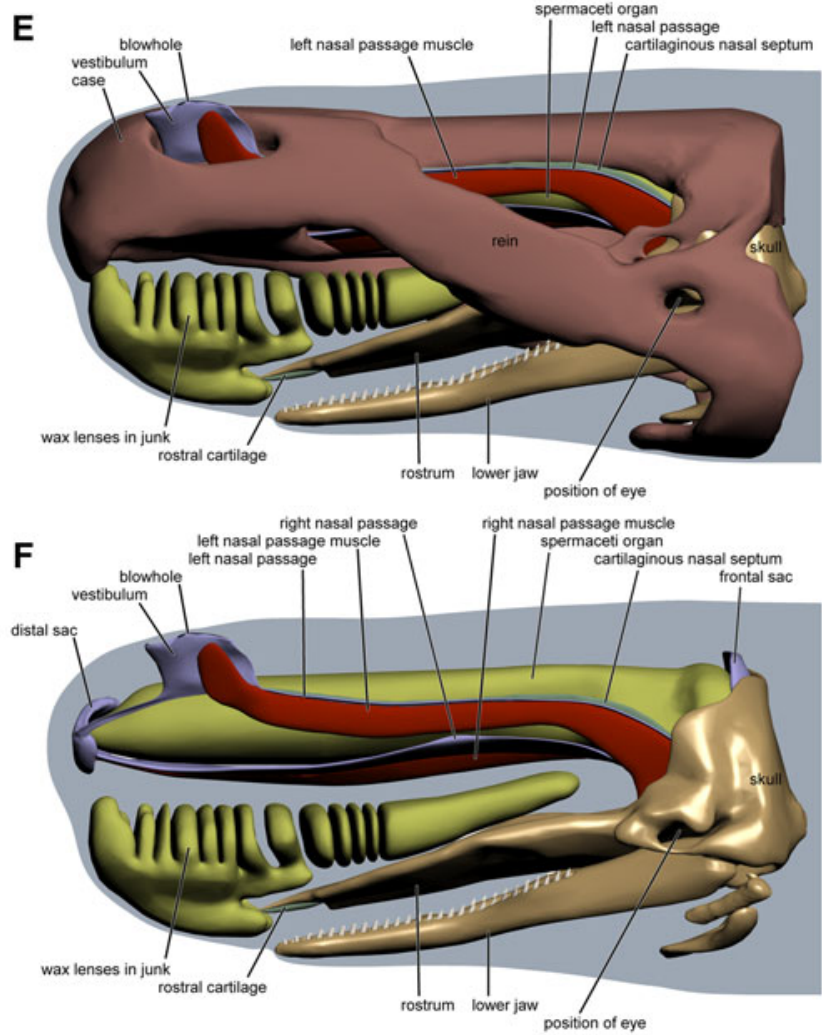

Fig. 1. Three-dimensional reconstruction of the head of an adult sperm whale. The major components of the nasal complex are colour-coded: brown, dense connective tissue (case, rein of case); purple, airways; beige, bony tissue (skull, lower jaw, hyoid bones); green, cartilage (rostral cartilage, septum nasi); red, muscle tissue; yellow, fat tissue. Other tissues, i.e. loose connective tissue surrounding the fatty structures of the junk, are not shown; shade of body in grey. (A) The right lateral view (dorsal pointing up) shows the extension of the superficial dense connective tissue (case, rein of case) and the maxillonasolabialis muscle. (B), Same view as (A); dense connective tissue and maxillonasolabialis muscle omitted. (C), Dorsal view (rostral pointing right); maxillonasolabialis muscle and dense connective tissue (case, rein of case) semi-transparent. The contour of the spermaceti organ demonstrates its close relationship with the underlying right nasal passage. (D), Left lateral view (dorsal pointing up). (E), Same view as (D); maxillonasolabialis muscle omitted. (F), Same view as (D); maxillonasolabialis muscle and dense connective tissue (case, rein of case) omitted. Note that it was not possible to include a scale into the figures because the reconstruction was not based on measurements of a single specimen. However, it is possible to estimate the dimensions of the reconstruction because figures A-F are in scale and measurements of nasal structures were provided by Clarke (1978b). 


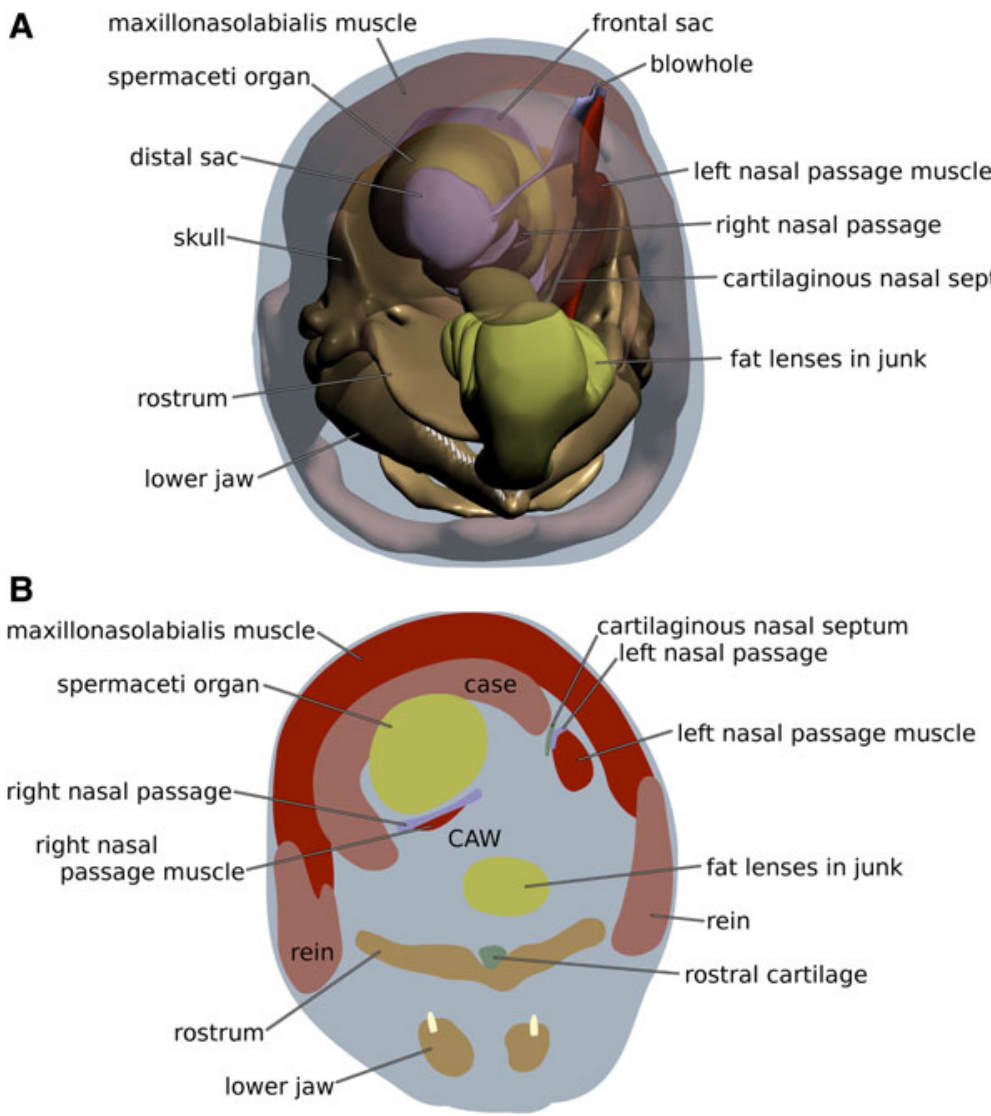

Fig. 2. (A), Frontal view of the reconstructed sperm whale head with the topography of the terminal acoustic window of the junk (see main text) and the distal sac; dense connective tissue (case, rein of case) and maxillonasolabialis muscle are semi-transparent. (B), Coronal section (dorsal pointing up) of the reconstructed sperm whale head. In the area of the connecting acoustic window (CAW; see main text) the spermaceti organ and junk are separated from each other by the oblique right nasal passage and the fatty right nasal passage muscle. The section level approximates Figure 3 , for colour code see Figure 1.

tube from the right bony nostril to the distal sac at the tip of the nose (Figures 1-4). The entrance of the right nasal passage into the distal sac is equipped with a pair of thick horizontal lips (museau de singe, monkey lips) consisting of extremely dense connective tissue confluent with the rostral part of the case (Figures 1, 4 \& 5). On the left, the distal sac is connected with the nasal vestibulum beneath the blowhole (Figure 1). At the caudal end of the spermaceti organ, where the skull forms a steep transverse wall behind the facial depression reminiscent of an amphitheatre (Figures 1 \& 6) (Norris \& Harvey, 1972), the right nasal passage opens dorsally into another flat sub-vertical air sac (frontal sac). Thus, the spermaceti organ borders both rostrally and caudally on extended air sacs. On top and on both sides, the spermaceti organ and the case, respectively, are surrounded by a strong layer of musculature (maxillonasolabialis muscle). The fibre bundles and tendons of this muscle run longitudinally from the dorsal edge of the amphitheatre to the connective tissue of the case behind the monkey lips (Figures 1-5).

The left nasal passage is very different from the right one in both shape and course. In contrast to the right nasal passage the left nasal passage runs rather superficially (Figures 1-3 $\& 5 \mathrm{~A}$ ) and is more prominent. The left nasal passage runs from the left bony naris to the vestibulum beneath the blowhole. Thus both nasal passages are interconnected with each other via the vestibulum and distal sac (Figures 1, 2 \& $5 \mathrm{~A}$ ).

The anatomy of the 'biggest nose on record' (Raven \& Gregory, 1933) has received a great deal of attention over time and thus various hypotheses regarding the function of this enlarged 'organ' came on file. Most suggestions as to the functional implications of the nasal complex fall into two broad categories: buoyancy regulation and sound generation. In the 1970s Clarke (1970, 1978a) expanded an earlier notion of Raven \& Gregory (1933) that the sperm whale might be able to control its buoyancy by alternately heating and cooling the large lipid structures within the nose. On the other hand, Norris \& Harvey (1972) proposed a primarily acoustic function for the sperm whale nose. This idea prompted Norris \& Møhl (1983) to suggest the possibility of acoustic debilitation of prey by means of the toothed whale nasal apparatus, a function that may have reached its zenith in the sperm whale. Recent examinations interpret this enormous nasal apparatus of sperm whales as a bio-acoustic machine capable of generating extremely loud click sounds by a pneumatic mechanism at the monkey lips (Cranford et al., 1996; Cranford, 1999; Møhl, 2001; Madsen et al., 2002a, 2003; Møhl et al., 2003a, b). Accordingly, the functional implications of this hypertrophied nose are not only respiration (adult toothed whales are anosmic) (Buhl \& Oelschläger, 1986; Kishida et al., 2007) but also the generation of the loudest sounds in the animal kingdom with source levels of up to $236 \mathrm{~dB}$ re $1 \mu \mathrm{Pa}$ (Møhl et al., 2000, 2003a; Zimmer et al., 2005b). Because large sound generation apparatuses can generate highly directional sound beams sperm whales have, additionally, longer detection ranges than small odontocetes (Madsen \& Surlykke, 2013). 
A

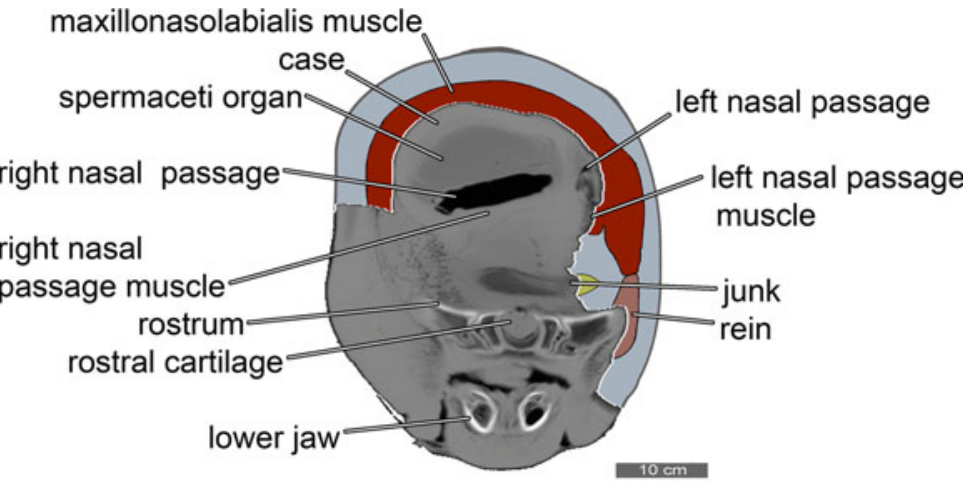

B

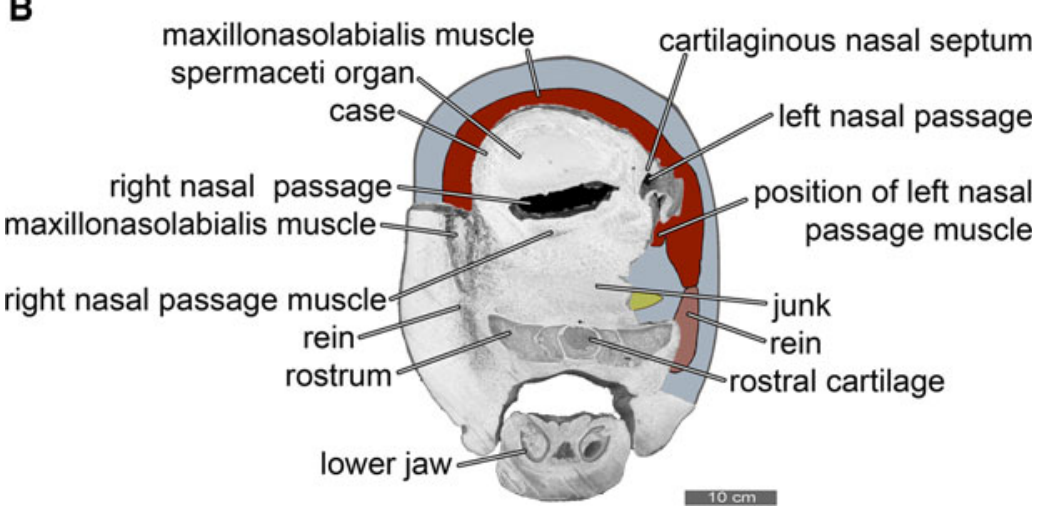

Fig. 3. Coronal section (dorsal pointing up) of a newborn sperm whale head through the area of the connecting acoustic window. The section levels approximate each other (cf. Figure 4A). CT scan (A) and cryo-section (B) of Calf 1 ; the superficial layers of the nasal complex (blubber fat as well as dorsal and left portions of maxillonasolabialis muscle) were removed prior to scanning to fit the head into the CT system; the original head contour was graphically reconstructed using the colour code of Figure 1. The right nasal passage is artificially widened due to tissue shrinkage by formalin fixation.

Sperm whales use different types of sounds to maintain their complex social relationships, to navigate and to locate prey. Accordingly, it has been suggested that highly directional clicks are involved in echolocation (Møhl et al., 2000; Jaquet et al., 2001; Teloni et al., 2005; Watwood et al., 2006; André et al., 2007) whereas stereotyped patterns of clicks, termed codas, are assumed to be less directional and may serve communication and social interaction (Watkins \& Schevill, 1977; Weilgart \& Whitehead, 1993; Møhl et al., 2000, 2003b; Madsen et al., 2002a; Marcoux et al., 2006; Watwood et al., 2006; Schulz et al., 2008). These click sounds of sperm whales typically consist of trains of rhythmically spaced, decaying pulses with centroid frequencies of $15 \mathrm{kHz}$ (Møhl, 2001; Møhl et al., 2003b). Further types of sperm whale vocalizations are listed in Table 1.

\section{CONSTRUCTION OF A 3D SPERM WHALE HEAD MODEL}

To demonstrate and interpret the complex three-dimensional anatomy of the sperm whale head and particularly of the dominating and asymmetric nasal complex we constructed a computer-based polygon model. For the construction of this model information from the literature was mainly based on in-depth examinations of two male young postnatal animals (calves), which were scaled up to the adult size (see below).

The head of Calf 1 ( $3.41 \mathrm{~m}$ total body length), which died in a temporary rehabilitation facility, was formalin-fixed. Further details of this specimen are published elsewhere (Ridgway \&
Carder, 2001; Huggenberger et al., 2006). After the removal of the superficial layers (skin, hypodermal layers and superficial muscles), this head was scanned using computer-assisted tomography (CT, slice thickness $0.9 \mathrm{~cm}, 6 \mathrm{dpi}$ ) and magnetic resonance imaging ( $\mathrm{T}_{1}$ and $\mathrm{T}_{2}$ weighted MRI, slice thickness $1.1 \mathrm{~cm}$, $13 \mathrm{dpi}$; Siemens Somatom and Siemens Magnetom scanners). The specimen was then cryo-sectioned into 13 coronal slices of approximately $5 \mathrm{~cm}$ thickness using a commercial band-saw and photographed. The remaining front and rear parts of the head including the monkey lips rostrally and the caudal end of the nasal complex was MRI scanned again (slice thickness $0.4 \mathrm{~cm}, 26 \mathrm{dpi}$ ) (Huggenberger et al., 2006) and dissected macroscopically.

The head of Calf 2 (4.25 $\mathrm{m}$ total body length) was studied by means of a complete CT data set available as a commercial screen saver developed by Ted W. Cranford (2013). Further details of the scanning procedure used for this specimen are published elsewhere (Cranford, 1999). After documentation of the scans, this specimen was carefully dissected at the Southwest Fisheries Science Center (National Marine Fisheries Service, San Diego, CA, USA). In this way, it was possible to control the results gained from the CT scans and to identify a series of structures not sufficiently characterized by computer tomography due to low differences in signal strength or resolution limits.

The data of Calf 1 and Calf 2 were verified by a series of photos of 10 coronal cryo-sections of approximately $7.8 \mathrm{~cm}$ thickness of a third calf $(4.21 \mathrm{~m}$ total body length NSMT M34233) kindly provided by T. Yamada (National Museum of Nature and Science, Tokyo, Japan). 

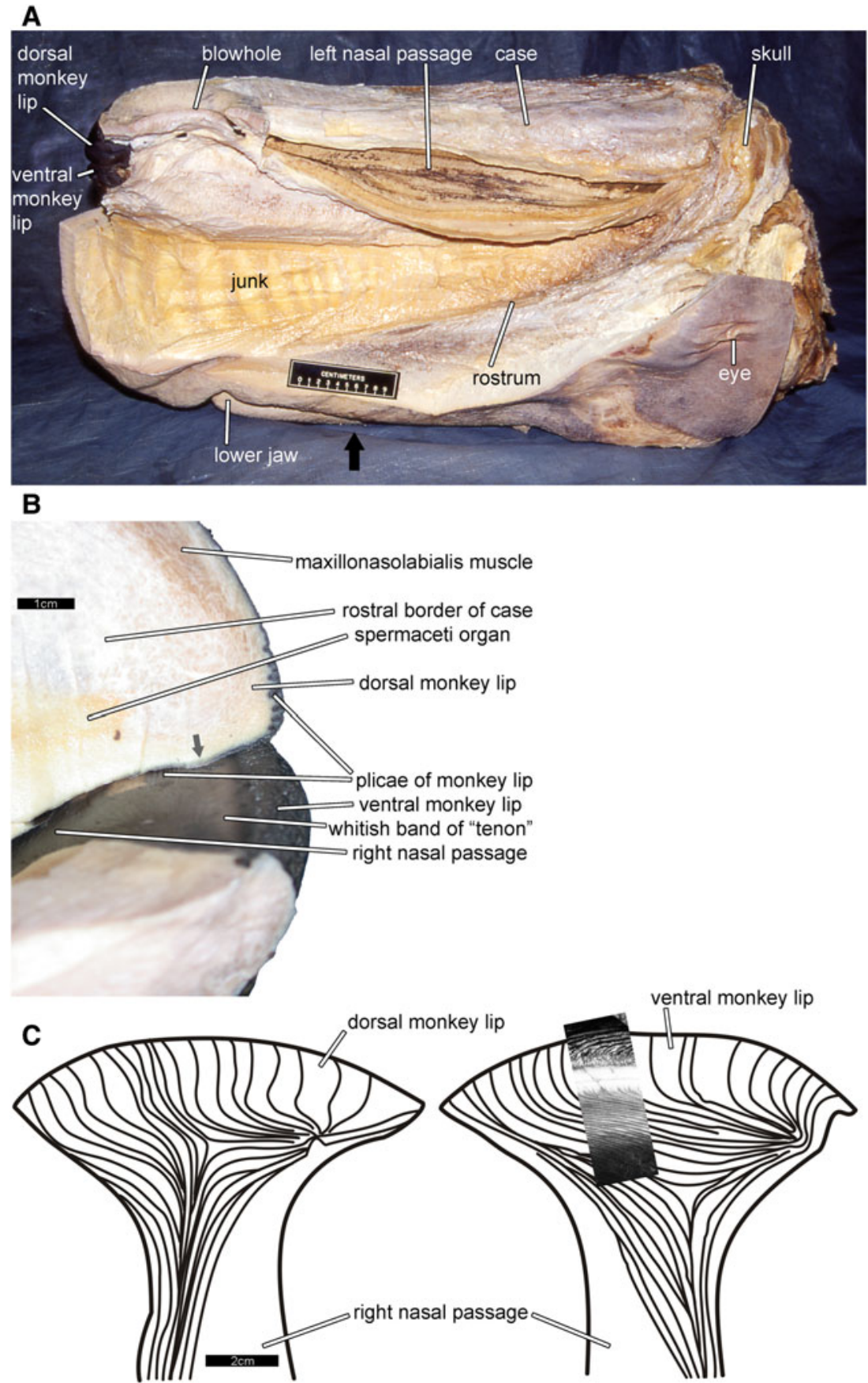

Fig. 4. Position and structure of the monkey lips in the sperm whale nasal complex. (A), Left lateral dissection of a sperm whale head (Calf 1 , dorsal points up). The maxillonasolabialis muscle is removed and the distal sac is opened to show the monkey lips. The junk is dissected para-sagittally (cf. Figure 3 ). The left nasal passage is opened and its muscle is removed (cf. Figure 3). Note that the black epithelium of the left nasal tract is detached. The arrow approximates the planes of the scan and the cryo-section in Figure 3. (B), Right lateral view of the sperm whale monkey lips (Calf 1 , rostral faces right, dorsal points up). The dorsal lip is removed up to its mid-sagittal plane so that the connection of spermaceti fat and connective tissue is visible. Grey arrow indicates the tongue of the groove and tongue complex of the lips. Note that the whitish band parallel to the groove and tongue folds is darkened due to the fixation of the specimen. (C), Schematic line drawing of the plicae on the inner surfaces of the distal right nasal passage and the monkey lips of Calf 1 (left: dorsal surface [upper monkey lip] in ventral view; right: ventral surface [lower monkey lip] in dorsal view; rostral facing up). Approximately one third of the total number of plicae is shown. The photo inset presents the actual surface of the ventral monkey lip of an adult sperm whale (photo width represents $5 \mathrm{~cm}$ ) projected on the same relative position and size in the drawing showing the whitish band of the groove and tongue complex. Note that young postnatal and adult sperm whales show the same pattern and about the same number of plicae on the monkey lips.

Additionally, the nasal complexes of two young sperm whale bulls (14.6 and $14.8 \mathrm{~m}$ total body length), stranded in 2002 in the Wadden Sea of the German Bight, were dissected superficially (monkey lips, distal and frontal sac regions, spermaceti organ). Further details for these specimens are published elsewhere (Huggenberger, 2004).
The anatomical data acquired were used to develop a threedimensional $(3 \mathrm{D})$ reconstruction of the adult sperm whale nose using 3ds max 2010 (Autodesk GmbH, Munich, Germany) in the following steps.

A prototype version of the model was created by Anthro Media (Berlin, Germany) and broadcast in a TV documentary 

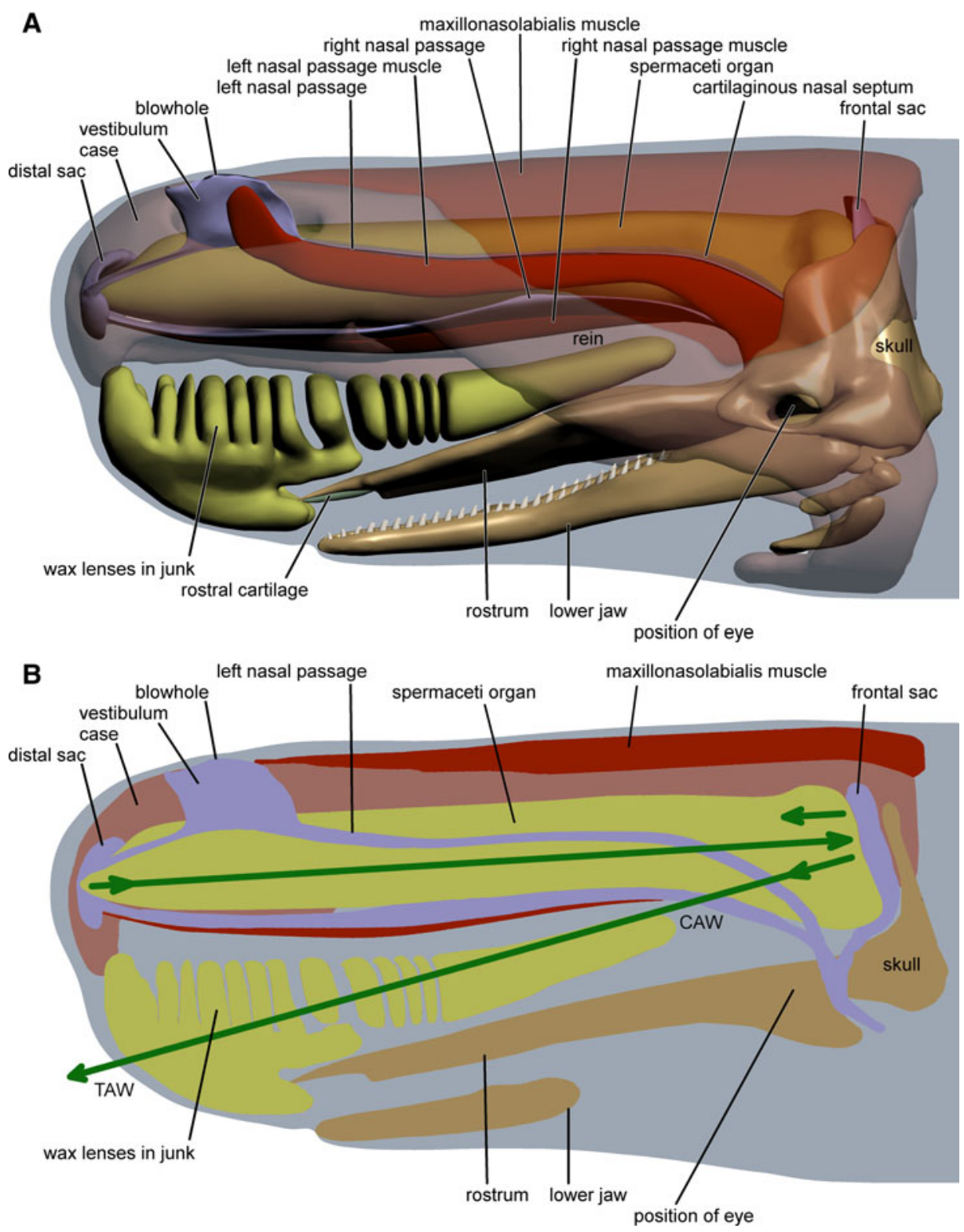

Fig. 5. (A), Left lateral view (dorsal pointing up) of the reconstructed sperm whale head; dense connective tissue (case, rein of case) and maxillonasolabialis muscle semi-transparent. (B), Sagittal view of the reconstructed sperm whale head (dorsal pointing up, tip of nose facing left). The green line represents the proposed acute-angled main acoustic pathway throughout the bent acoustic horn (Møhl, 2001) and their (preceding) reverberation within the spermaceti organ (theory of Norris \& Harvey (1972); see main text). On its presumed path, the sound waves travel through the connecting acoustic window (CAW) into the junk and are released via the terminal acoustic window (TAW) into the water (bent acoustic horn hypothesis (Møhl, 2001); see main text).

(Anthro Media, 2008). Starting with this prototype we added further information and structures to the $3 \mathrm{D}$ model step by step by using $2 \mathrm{D}$ pixel graphics as templates which were temporarily positioned within the $3 \mathrm{D}$ model. The shapes of internal structures were modelled by hand using $3 \mathrm{ds}$ max and aligned to these templates. The templates were (1st) MRI figures and photos of cryo-sections of Calf 1 in transverse planes and mid-sagittal plane (MRI) and (2nd) hand-made segmentations of single sections of the CT data set (screen saver) in horizontal, transverse and sagittal planes of Calf 2. These latter segmentations were drawn on overhead transparencies fixed on the computer screen and scanned to grey-scale $2 \mathrm{D}$ pixel graphics afterwards.

Thereafter, allometric changes from the calf to the adult were considered on the basis of photos of an adult female skull in lateral and dorsal view (Figure 6) and measurements of the adult male skull stored in the British Natural History Museum in London (UK; skull length approximately $500 \mathrm{~cm}$ ). These measurements were plotted as a series of $2 \mathrm{D}$ plots and used as additional templates in $3 \mathrm{ds}$ max. Moreover, we used figures and descriptions of the anatomy of adult sperm whales in numerous publications (Flower, 1867; van Beneden \& Gervais, 1868; Clarke, 1970, 1978b; Behrmann \& Klima, 1985; Klima et al., 1986a, b; Gambell, 1995; Cranford, 1999; Klima, 1999, 1990; Huggenberger, 2004; Huggenberger et al., 2006; Nakamura et al., 2013) to adjust allometric changes by hand. As the last step we adjusted the shape of the whole nasal complex including internal structures (except the skull and bordering surfaces) to the external shape of sperm whale heads using lateral and dorsal 


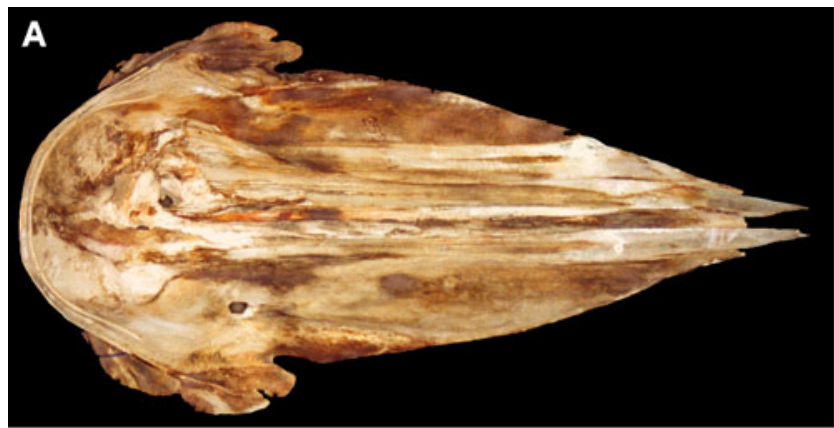

B

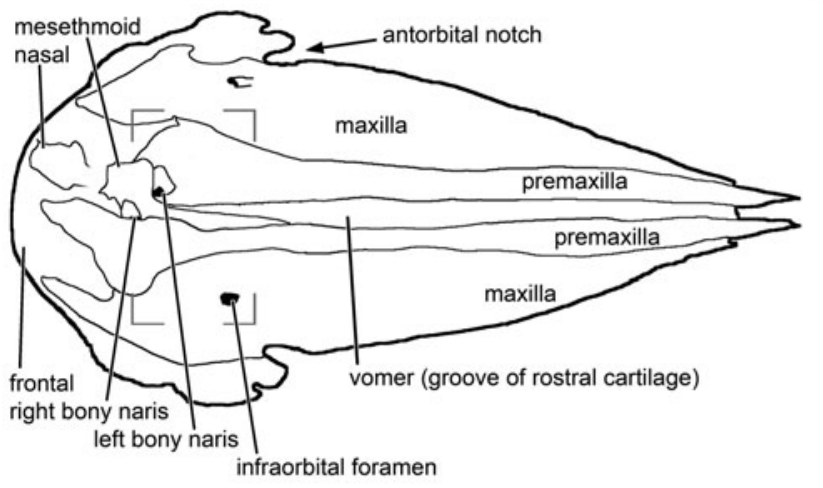

groove of rostral cartilage on vomer mesethmoid
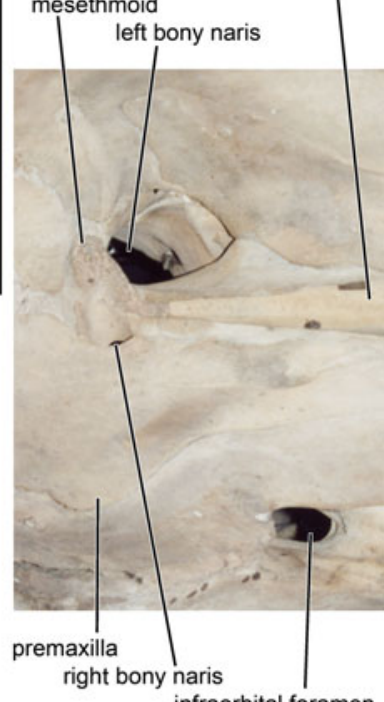

C

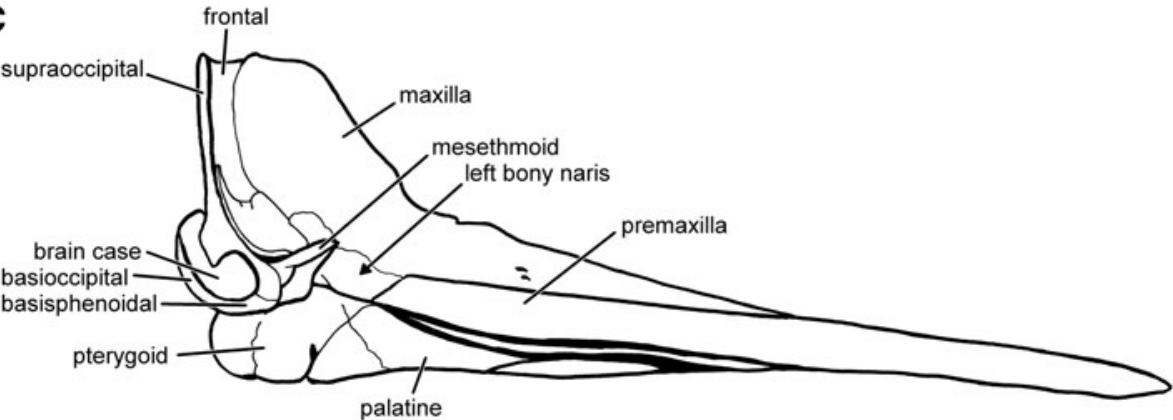

Fig. 6. (A), Dorsal view of the skull in the adult female sperm whale (rostral pointing right; skull length $330 \mathrm{~cm}$; specimen no. 253051) shows its main components, the long rostrum (right two-thirds) and the amphitheatre (left third). The scheme below shows the borders of the individual structures. Inset approximates the borders of close-up (B), which was, however, taken from a sub-adult sperm whale bull skull (length $150 \mathrm{~cm}$; specimen no. 35315 ) to show the area of the bony nares. (C), Scheme of a medial view of a mid-sagittal section of the skull of an adult male sperm whale (skull length $\sim 580 \mathrm{~cm}$; specimen no. 301634 ). The skulls are stored in the National Museum of Natural History, Smithsonian Institution, Washington, DC, USA.

underwater photos and figures from textbooks as templates (Martin, 1991; Ellis, 1996; Steffen \& Steffen, 2003).

Whereas there seems to be good correspondence between all postnatal animals as to the morphology and topography of the nasal structures, there are some points of uncertainty regarding the anatomy of the adult in comparison to that of the calves: it is not known how many lens-like fat bodies exist in the junk of adult sperm whales and whether they are connected with each other rostroventrally as is the case in calves. According to the schematic sagittal section in Clarke (1978b) the number of lenses in the adult animal is similar to that in calves but a ventral connection between the rostral lenses was not described in adults. Moreover, we do not know the exact shape of the adult spermaceti organ and the exact topographical relations of the nasal components to each other because it is not possible to apply three-dimensional imaging methods, such as CT and MRI, to adult sperm whales due to their size. In order to get a maximum of information into our three-dimensional reconstruction of an adult sperm whale head, we extrapolated these reconstructions of our young sperm whale calves to the dimension and external form of adult sperm whale heads. In the case of details such as the number, shape and connections between lenses as well as the shape and size of the spermaceti organ, the data of the calves supplied by CT scanning are probably more correct than macroscopic dissections of the large adults, which are extremely difficult to handle.

\section{TOPDGRAPHICAL ANATOMY}

\section{Skull}

Within the toothed whale group, the skull of the sperm whale is unique in its size and shape (Figures $1,5 \& 6$ ). It consists of slender jaws and a compact brain case. The anterior part of the upper skull is represented by the flat and elongate rostrum (vomer and rostral cartilage, upper jaw elements), which tapers like a wedge at its anterior end (Figures $1 \mathrm{C} \& 6$ ). Caudally, the skull extends into a 
Table 1. Principal types of sperm whale clicks. Other vocalizations, e.g. chirps, gunshots, pips, squeals, squarks or yelps that have been reported from sperm whales are considered to be a likely result of rapid sequences of clicks, the functions of which remain unclear (Goold, 1999; Madsen, 2002; Whitehead, 2003; Weir et al., 2007). Calf grunts of low directionality and centroid frequencies around o.5 $\mathrm{kHz}$ are thought to be generated at the connection between the right nasal passage and the frontal sac (Madsen et al., 2003). The trumpet sounds are a likely by-product of the click generation mechanism (Teloni et al., 2005).

\begin{tabular}{|c|c|c|c|}
\hline Sounds & $\begin{array}{l}\text { Directionality } \\
\text { (centroid frequency) }\end{array}$ & $\begin{array}{l}\text { Decay rate of } \\
\text { pulse's intensity }\end{array}$ & Proposed function \\
\hline Calf click & Low $(0.5 \mathrm{kHz})$ & Single-pulsed & Communication (Madsen et al., 2003) \\
\hline Chirrup click & $-(5 \mathrm{kHz})$ & Low & Communication (Madsen, 2002) \\
\hline Coda click & Low $(5 \mathrm{kHz})$ & Low & $\begin{array}{l}\text { Communication (Watkins \& Schevill, 1977; Watkins et al., 1985; } \\
\text { Weilgart \& Whitehead, 1993; Whitehead \& Weilgart, 2000; } \\
\text { Madsen, 2002; Madsen et al., 2002a) }\end{array}$ \\
\hline Creak click & High $(15 \mathrm{kHz})$ & High & $\begin{array}{l}\text { Buzzes used for homing echolocation (Madsen, 2002; Madsen et al., } \\
\text { 2002b; Whitehead, 2003) }\end{array}$ \\
\hline Rapid click & $\operatorname{High}(-)$ & Single-pulsed & Echolocation? (Goold, 1999; Madsen et al., 2002b) \\
\hline Slow click (clang) & Low (3 kHz) & $\begin{array}{l}\text { Low ( faint multi-pulsed } \\
\text { structure) }\end{array}$ & $\begin{array}{l}\text { Long-range communication (Weilgart \& Whitehead, 1993; } \\
\text { Whitehead \& Weilgart, 2000; Madsen et al., 2002b; Whitehead, } \\
\text { 2003; Oliveira et al., 2013) }\end{array}$ \\
\hline Usual click & High $(15 \mathrm{kHz})$ & High & $\begin{array}{l}\text { Mid-range echolocation* (Madsen et al., 2002b; Møhl et al., 2003b; } \\
\text { Teloni et al., 2008) }\end{array}$ \\
\hline
\end{tabular}

*The term 'mid-range echolocation' refers to distances of at least several hundreds of metres (André, 2009).

transverse and sub-vertical caudal crest above and behind the brain case and just before the level of the occipital condyles (Figures 1 \& 5). The rounded inner surface of this caudal crest, reminiscent of an amphitheatre (Norris \& Harvey, 1972), is formed predominantly by caudal elongations of the broadened upper jaw elements (premaxillaries, maxillaries; Figure 6). The neurocranium, extending from the rostral end of the ethmoid region to the occipital condyles, is short with respect to the broad rostrum. Due to the disproportionate growth of the skull in adult sperm whales, the neurocranium with the brain gets restricted to the caudalmost part of the skull base (Figure 6C). Apparently, the very low position of the brain case is due to the fact that the back of the amphitheatre (supraoccipital crest) has become extremely high: the latter anchors the hypertrophied nasal complex caudally and, at the same time, acts as an attachment site for the strong superficial muscles which run to the blowhole area and hold the hypertrophied nasal complex in position (maxillonasolabialis muscle, see below).

As in other cetaceans, the bony nostrils in sperm whales lead ventrally into short, nearly vertical bony passages and to the inner nasal openings (bony choanae). These passages have a smooth inner surface and lack nasal conchae. In contrast to other toothed whales, the two bony nasal openings of sperm whales strongly differ in size (Figure 6; see below), with the left naris being much wider than the right one. Due to a general asymmetry of the facial skull in toothed whales, the associated bony elements (premaxillary, maxillary bone) on the right side of the naris region are wider and the area of the bony nares is slightly twisted clockwise (dorsal aspect) so that the small right bony nostril is situated caudal to the level of the large left bony nostril (Figure 6).

The zygomatic arch, thin and rod-like in other toothed whales and forming the ventral border of the orbita, is robust in sperm whales (Figures $1 \& 5 \mathrm{~A}$ ). It seems that, on both sides, this element, which mediates between the maxillary, frontal and squamosal bones, may help to stabilize the supraoccipital crest. For the same purpose, the postorbital process of the frontal and the squamosal bone come close to one another and the intermittent gap is bridged by dense connective tissue (secondary zygomatic arch) (Oelschläger, 1990).

\section{Nasal passages}

Unique among the toothed whales the blowhole of sperm whales is situated rostrodorsally at the tip of the snout (Figure 1). Accordingly, the nasal passages have been extended into elongated tubes lined by brown or black epithelium and run from the blowhole region in a ventrocaudal direction to the bony nares in the deep facial depression of the skull (Figures $1 \& 5$ ). Additionally, in the sperm whale, the blowhole is peculiar in its shape, i.e. it is located on the lefthand side near the dorsal tip of the snout and S-shaped in dorsal view (Figure $1 \mathrm{C}$ ). It leads into a vestibule which, standing parasagittally, has two additional openings (Figure $1 \mathrm{C}, \mathrm{F}$ ): the rostroventral corner is continuous with the distal sac via a narrow channel and the caudoventral corner of the vestibule opens into the left nasal passage. This passage runs directly caudally below the left surface of the nose but gradually arches ventrally along the cartilaginous nasal septum (Klima, 1999) to the wide left bony naris (Figures 1 \& 6). Along most of its course the collapsed left nasal passage is C-shaped in cross-section. This crescent shape is due to the bulging of the left nasal passage muscle lateroventrally into the lumen of this passage (Figures $2 \& 3$ ).

In contrast, the right nasal passage is broad, flattened dorsoventrally, and runs rostrocaudally between the two hypertrophied fat bodies (spermaceti organ and junk; Figures 1-3 \& 5). This passage opens rostrally into the distal sac (Figures $1 \&$ 5) which extends behind the dorsorostral tip of the snout, and caudally into the frontal sac. Interestingly, there is a striking difference between the size (area) of the epithelial lining in the two nasal passages: the inner surface of the right passage is more than twice as large as that of the left passage (Figures 2 \& 3). This is in strict contrast to the size of the associated bony nares, where the diameter of the right opening is only one third to one fourth that of the left (Figure 6). The dissection of non-fixed dead stranded 
specimens showed that the left nasal passage was always partially open and the right passage was collapsed, leaving two narrow lateral channels running to the distal sac (except in Calf 1 , Figure 3 A, probably due to tissue shrinkage during formalin fixation).

The aperture between the flattened right nasal passage and the distal sac is equipped with a special type of outlet which superficially resembles the lips of a monkey and accordingly was termed 'museau de singe' (Figures $1 \& 4$ ) (Pouchet \& Beauregard, 1885). In the sperm whale, these monkey lips are a thick flap valve consisting of extremely dense collagen which frame the slit-like aperture and seem to represent an airtight valve because these lips are closed tightly in dead animals (Norris \& Harvey, 1972). The monkey lips are slightly inclined to the right side so that the left angle of the 'gape' stands higher. The plane of the rostral part of the right nasal passage shows the same degree of inclination (Figures 1-3) but gradually becomes horizontal towards the right bony naris.

Inside the aperture, the epithelium of the monkey lips is differentiated as a groove and tongue structure paralleling the 'gape' of the lips (Figure $4 \mathrm{~B}$ ). The lower lip forms the groove and the upper lip represents the tongue component. Whereas the monkey lips are covered with black epithelium, the opposing surfaces of the groove and tongue structure are whitish in fresh animals (Figure 4; in Figure $4 \mathrm{~B}$ this band is darkened probably due to the formalin fixation of the specimen). Next to the groove and tongue structure of the monkey lips the epithelium forms tiny furrows or plicae (Figure $4 \mathrm{C}$ ). These plicae originate from a centre at the right lateral margin and approximately $10-15 \mathrm{~cm}$ caudal to the monkey gape and fan out over the whole width of the monkey lips (Figure $4 \mathrm{C}$ ). The set of plicae runs from the centre along the right lateral channel of the right nasal passage caudally (Figure ${ }_{4} \mathrm{C}$ ).

The frontal sac, as the second accessory nasal air space, extends on the concave rostral slope of the amphitheatre and covers most of its surface (Figures 1 \& 5; see below). Via a narrow extension this sac communicates with the right nasal passage just dorsal to the right bony nostril. The rostral wall of the frontal sac is represented by the smooth caudal surface of the spermaceti organ. The caudal wall of this air sac comprises a sheet of connective tissue which is attached to the back of the amphitheatre and covered by an epithelium equipped with small bubbles filled with serous liquid (Norris \& Harvey, 1972).

\section{Nasal fat bodies and dense connective tissue}

The sperm whale's nose mainly consists of two big longitudinal fat (wax) bodies, the ventral junk and the dorsal spermaceti organ. As a whole, the junk is characterized by the shape reminiscent of a blunt and stout hatchet. It rests on the bony rostrum of the skull and has, at least in its rostral part, a nearly symmetrical position within the sperm whale's head (Figures $1-3$ \& 5). In its caudal third, the junk is flanked by two thick lateral ribbons of dense connective tissue (reins of case; Figures $1 \& 2$ ). Although the junk shapes the ventral tip of the sperm whale snout, it is distinctly shorter than the spermaceti organ. It ends caudally well before the level of the bony nares (Figures $1 \& 2$ ). In detail, the junk represents a complex structure and consists of loose connective tissue in which parallel lens-like fatty elements are embedded. Each lens is oriented vertically and the whole set of lenses extends caudally between the spermaceti organ and the bony rostrum (Figures $1,4 \mathrm{~A} \&$ 5). Here, the junk is separated from the fat of the spermaceti organ by the right nasal passage and its fatty muscle (Figures $1-3 \&$ 5), an important detail for functional considerations (connecting acoustic window; see below). Interestingly, the rostral-most lenses are confluent ventrally to form a rounded extension of the nose which hangs over the tip of the bony rostrum, just before the gape of the mouth (Figures 1 \& 5). In this rostral part, the junk fat reaches the surface of the sperm whale head and is free from the reins of the case. Caudally, both the layers of loose connective tissue and the lenticular elements progressively become thinner and the lenses merge into a continuous and tapering fatty cone (Figure 1). This cone, also reminiscent of a 'mouth-piece', turns slightly dorsocaudally along the bottom of the skull amphitheatre and in the direction of the frontal air sac; it ends between the skull roof and the caudal portion of the spermaceti organ. The whole set of fatty elements in the junk thus resembles a cornucopia or funnel.

Within the hypertrophied nose, the dominant structure is the cylindrical to fusiform spermaceti organ which contributes much to the size and shape of the sperm whale head as a whole. This 'organ' spans the entire length of the nasal complex between the monkey lips rostrally and the back of the amphitheatre caudally (Figures $1,4 \mathrm{~A} \&$ 5). Whereas the apex of the spermaceti organ is located slightly to the right of the nose it ends caudally in the centre of the amphitheatre, just above the right bony naris (Figures $1 \& 5$ ). This fat body rests on the junk and is enclosed in a thick sheath of connective tissue referred to as the case (Figures 1-5) (Raven \& Gregory, 1933). Rostrally, the case of the spermaceti organ is continuous with the concave monkey lips (Figures 1, 4 \& 5). According to the CT data sets available, the connective tissue of the case in our larger sperm whale head (Calf 2) attains its maximal density in the monkey lips. The taut case consists of a tough criss-cross network of collagenous fibres, and it keeps the soft fat tissue in shape. The case opens ventrally and to the left so that the junk and the spermaceti organ are only separated by the right nasal passage and its fatty muscle (Figures $1-3 \& 5$ ). The blunt caudal end of the spermaceti organ, being slightly oval in cross-section, rests with its flat and smooth surface on the sub-vertical back of the amphitheatre with its bubble-containing epithelium. The smooth surface of the spermaceti organ in this area and the irregular surface of the epithelium on the amphitheatre constitute the frontal air sac.

On both sides, the epicranial complex with its fat bodies is surrounded by oblique ribbons of superficial subdermal dense connective tissue which we refer to as reins of the case and which encompass and suspend the soft tissues of the nose from the rear part of the skull (Figures 1-3). In the dorsorostral region of the nose (blowhole and monkey lip area), the rein passes into the case, with the distal sac being interposed between the two collagenous structures (reins of case, monkey lips; Figures $1-3 \& 5$ ). Obviously, this complex of dense connective tissue at the dorsorostral tip of the sperm whale nose serves as an attachment site for the tendons of the maxillonasolabialis muscle (Figure 1; see below). In our three-dimensional reconstruction of an adult sperm whale head all this collagen (reins, tendons, case) forms a thick dorsal and lateral sheath around the rostral half of the 
spermaceti organ (Figures $1 \& 5$ ). In contrast, the rostroventral region of the epicranial complex is free from the reins (Figures $1 \& 5$ ) so the junk is largely subcutaneous here.

\section{Nasal cartilages}

In the sperm whale forehead, there is a fork-like cartilaginous structure (Y-shaped in lateral view). The short base of this fork originates from the edge of the mesethmoid bone between the bony nares (Figures $1-3 \& 6$ ). The small plate of the mesethmoid bone and the base of the fork are inclined to the left side of the head and partially cover the wider left bony naris (Figure 6). The ventral prong of this fork, the rostral cartilage (syn. mesorostral cartilage, cartilaginous rostrum, rostrum nasi) (Klima, 1990, 1999), is rod-like and extends along the longitudinal groove of the vomer (mesorostral canal) between the premaxillary bones as far as the tip of the rostrum (Figures $1-3 \& 6$ ). This rostral cartilage develops from the embryonic septum nasi (Klima, 1999).

The dorsal prong of the cartilaginous fork, referred to as nasal roof cartilage and formed by the embryonic tectum nasi and septum nasi, is a thin and slender perpendicular blade which follows the medial wall of the left nasal passage on its way to the blowhole (Figures 1-3 \& 6) (Klima, 1999). Thus, the cartilage describes part of a spiral as it first moves to the left and dorsally along the concave skull roof, then bends dorsorostrally and runs between the left nasal passage and the case of the spermaceti organ. In its initial (ventrocaudal) segment the cartilage appears irregular in shape and wavelike (Huggenberger et al., 2006). These 'waves' were not reconstructed in our three-dimensional model of an adult sperm whale head. However, the nasal roof cartilage was reconstructed to approximate the dimensions found in the literature: in the full-grown sperm whale, this cartilage (Klima, 1999 ) is several metres long, about $32-45 \mathrm{~cm}$ high (dorsoventral extension) and 18-35 mm thick (Behrmann \& Klima, 1985). In the direction of the blowhole the nasal roof cartilage tapers markedly and, in the adult whale, dissolves and comes close to an ovoid arrangement of about a dozen isolated pieces of cartilage, so-called nostril cartilages, that underlie the sigmoid blowhole (diameter of ovoid arrangement about $80 \mathrm{~cm}$ in a whale of $18 \mathrm{~m}$ length) (Behrmann \& Klima, 1985; Klima, 1990). In the sperm whale calves, no such arrangement of cartilaginous elements around the blowhole was found and was not reconstructed in our threedimensional model of an adult sperm whale head.

\section{Nasal musculature}

The large maxillonasolabialis muscle of the sperm whale runs straight from the lateral and caudal margins of the amphitheatre in the rear part of the skull to the blowhole region (Figure 1). The prominent dorsal part originates from dense connective tissue at the vertex of skull and ensheaths the spermaceti organ dorsally and laterally. Halfway to the blowhole this dorsal muscle transforms into a layer of numerous strong tendons (Figure ${ }_{4} \mathrm{E}$ ), which pass into the extremely dense tissue at the upper monkey lip and case, respectively, surrounding the spermaceti complex. According to the fibre orientation, the contraction of this longitudinal part of the dorsal maxillonasolabialis muscle should pull the blowhole area and the spermaceti organ caudalward and slightly upward. Two additional portions of this muscle originate on both sides of the skull along the lateral margins of the amphitheatre between the antorbital notch and the infraorbital foramen (Figures $1 \&$ \&). From here, they run obliquely to the sides of the monkey lips where they attach. A slight asymmetry is obvious: the oblique muscle on the right side is wider in cross-section than its counterpart on the left-hand side and reaches further ventrally (Figures $1-3$ ). Together, the dorsal and lateral parts of the maxillonasolabialis muscle resemble an asymmetric 'inverse half-pipe' surrounding the case superficially.

Two other skeletal muscles accompany one nasal passage each. The left nasal passage muscle (Figures 1-3) extends from the left bony naris rostrally to the vestibulum below the blowhole. On its way it shows a constant topographical relationship to the left nasal passage and the nasal roof cartilage, with the air passage in a more dorsal position, the cartilage medial to it and the muscle immediately left and more ventral to the passage (Figures $1-3 \& 7$ ). In our sperm whale calves, the left muscle bulges into the left nasal passage; its fibre bundles are relatively short, run perpendicular to the lateral wall of the passage ventrally and attach to the connective tissue of the junk. As tested by parallel pull of the muscle fibres, the muscle should be able to open the left nasal passage. In the caudal part, where the left nasal passage turns ventrally, the left nasal passage muscle is thick and club-shaped and occupies the space between the spermaceti organ and the left wall of the amphitheatre. Concluding from the orientation of its fibres in a more rostrocaudal direction, this strong part of the muscle can pull the rostral wall of the left nasal passage rostrally in order to open the entrance into the left bony nasal canal.

The right nasal passage muscle (Figures $1-3$ ) is flat, nearly band-shaped and rich in fat. It starts from the right bony naris, runs below the right nasal passage, and ends caudal to the lower monkey lip. The texture of the fibre bundles in the right nasal passage muscle is diffuse which makes the definition of its ventral and lateral margins in the scans and in the three-dimensional reconstruction of an adult sperm whale head difficult. Most fibres run rostroventrally and thus should be able to open the right nasal passage on contraction.

\section{FUNCTIONAL INTERPRETATION DF THENASAL COMPLEX}

In the sperm whale head, the skull is relatively small and only comprises about $11 \%$ of total head mass (i.e. 2.2 tons of as much as 20 tons; example: adult male of $18 \mathrm{~m}$ length and 57 tons total body mass) (Behrmann \& Klima, 1985). The remaining $89 \%$ of the head is represented mostly by soft tissue of the nasal complex and its accessory structures, particularly the extremely large fat bodies (junk, spermaceti organ). Thus the skull 'is degraded to a marginal structure' (Klima, 1990), which can only incompletely seat this exceptionally large epicranial complex. An important accessory suspension seems to be granted by the reins of the case consisting of dense collagen which also serve as attachment sites for the longitudinal and oblique (maxillonasolabialis) muscles. On both sides the reins originate around the zygomatic arch, which is rather thick and strong in the sperm whale in comparison with the situation in other toothed whales, leaving an 'orbita' free of connective tissue (Figure 1). Accordingly, on both sides of the head, the zygomatic arch is part of an 
attachment site for subdermal tough connective tissue of the reins of the case which suspend the rostral part of the nose from the lateral margins of the amphitheatre (Figures $1 \& 5 \mathrm{~A}$ ).

\section{Respiration}

As mentioned above, the two nasal passages in the sperm whale are disparate in shape and topography and obviously specialized for different functional requirements (Norris \& Harvey, 1972; Huggenberger et al., 2006). This is already obvious in the general appearance of the two canals. Whereas the left nasal passage has about the same diameter along its whole course including the left bony nostril, the right nasal passage is characterized by marked changes in shape and width. Thus, the right passage, situated between (a) the right bony nostril and the monkey lips and (b) between the two large fat bodies, appears more like a bellows that serves as a reservoir for air. More specifically, the considerable size difference in the aperture of the two external bony nasal openings in the skull of the sperm whale can be correlated with differences in the presumed function of the associated nasal passage: The wide left bony naris is a simple continuation of the left nasal passage running directly to the blowhole, and it is responsible for quick and efficient breathing during surfacing (Huggenberger et al., 2006). In contrast, the narrow right bony naris leads to the monkey lips via the enlarged right nasal passage which has two additional extensions (frontal and distal sac) and seems to be involved in phonation (Norris \& Harvey, 1972; Møhl, 2001). In other words, whereas the left nasal passage may serve the quick exchange of large quantities of air under high pressure, the right passage may deal with relatively small quantities of air (as indicated by the small diameter of the right bony naris) during phonation both at the surface and during diving, when water pressure shrinks air spaces to tiny volumes. Due to this functional separation, sound generation of a sperm whale could be observed during respiration (Wahlberg et al., 2005).

From the topographical situation in sperm whale calves it appears that the slender, flat and thus blade-like nasal roof cartilage, which runs along the left nasal passage medially, probably stabilizes the left passage against the pull of the left nasal passage muscle which opens it (Klima, 1990, 1999). This may prevent the passage from collapse during negative pressure events of inhalation. The massive presence of elastic fibres within the hyaline cartilaginous tissue of the dorsal roof cartilage was interpreted as a possible adaptation to repetitive deformation of this structure during such events of high pressure gradients (Huggenberger et al., 2006).

\section{Sound generation and emission}

Pouchet \& Beauregard (1885) first described the enigmatic 'museau de singe' within the sperm whale nose. As stated above, this bipartite valve is believed to be the initial site of sound generation (Cranford et al., 1996; Cranford, 1999; Møhl, 2001; Ridgway \& Carder, 2001; Møhl et al., 2003a). The initial pulse of a sperm whale click is thought to be produced by a pneumatically driven clapping mechanism in which air is transported from the right nasal passage via the gape of the monkey lips into the distal sac (Norris \& Harvey, 1972). As is hypothesized for other toothed whales, the air stream 'passes forward between the monkey lips, causing them to open and then slap together in a series of events whose repetition rate is regulated by factors such as air pressure and/or muscle tension on vibratory elements' (Cranford et al., 1996). Vibrations of the monkey lips caused by high-pressure injection of air through the aperture of the lips are presumably transferred to the tip of and into the fusiform spermaceti organ. The concentric organization of the spermaceti organ seen in adult animals as well as the impedance mismatch at the boundary between the fat body and the case may help to channel the sound waves coming from the monkey lips backward in the direction of the frontal sac. Acoustic impedance mismatch between neighbouring structures is correlated (among other factors) to differences in tissue density visualized in the CT scans. It is therefore highly probable that the caudal end of the spermaceti organ (resembling a drumhead), the adjacent air space, the opposing epithelium of the frontal sac as well as the osseous back of the skull amphitheatre form a multi-layered structure by which sound can be reflected. The caudal inner surface of the frontal sac is equipped with a field of densely packed bubbles containing serous fluid. Norris \& Harvey (1972) saw the function of these bubbles in the capture and distribution of small volumes of residual air in a filigree of communicating air spaces. Thus, the incompressible bubbles may help to resist total collapse of the frontal sac under high pressure during deep dives of the animals.

According to Norris \& Harvey (1972) the pulse pattern within the clicks is the result of one initial pulse generated pneumatically at the monkey lips (Cranford et al., 1996), its multiple reflections between the two opposed acoustic mirrors (distal sac and frontal sac; Figure $5 \mathrm{~B}$ ) and thus the repetitive travelling of sound within and along the spermaceti organ. Therefore, the inter-pulse interval should represent the two-way sound travel time between the acoustic mirrors (Norris \& Harvey, 1972; Cranford, 1999; Mathias et al., 2009). However, this theory does not answer the question whether the junk has a potential acoustic function. A recent hypothesis developed by Møhl and co-workers (Møhl, 2001; Møhl et al., 2003a, b; Zimmer et al., 2005b) supports the Norris \& Harvey theory (1972) and proposes a sound path through the junk into the water (Figure ${ }_{5} \mathrm{~B}$ ). In this model, the spermaceti organ and the junk together form a bent 'acoustic horn' in which, as a first step, sound generated at the monkey lips is reflected to and fro by air-filled cavities (distal sac and frontal sac). The initial click is reverberated several times within the spermaceti organ (Norris \& Harvey, 1972; Cranford et al., 1996; Møhl, 2001; Ridgway \& Carder, 2001; Møhl et al., 2003a, b) and, during each cycle, part of the sound energy exits into the junk. From here, the sound is guided into the water at the lower tip of the nose (Zimmer et al., 2005a). By means of the fat lenses and the intermediate soft connective tissue in the junk, sound may be guided to the front of the head and emitted into the water. This 'bent acoustic horn hypothesis' (Møhl, 2001; Møhl et al., 2003a, b; Zimmer et al., 2005b) explains why most of the sperm whale clicks consist of a series of decaying pulses as well as how and where these individual pulses are produced and released into the water. Moreover, it explains a 'leakage' of sound energy which can be observed between the pulses and is interpreted as direct reflections from the frontal sac (Norris \& Harvey, 1972; Ridgway \& Carder, 2001; Schulz et al., 2008).

The potential function of the fatty lenses of the junk as acoustic lenses was first outlined by Kenneth S. Norris in 
the 1980s (Cranford, 1999). On its way through the junk, sound may be focused by the lenticular structures (Møhl, 2001) since fat tissue has lower sound propagation velocities than the intercalated connective tissue of the junk (Malins \& Varanasi, 1975; Flewellen \& Morris, 1978; Goold et al., 1996). Thus the stack of lenticular fat bodies seems to represent an acoustic pathway along the axis of this system (Figure 5B). In the rostroventral region of the junk, however, the tissue is more or less homogeneous and the fat lenses merge ventrally into a larger fat body in the two calves examined. In this area the junk tapers from the sides in the ventral direction, with the superficial fat being located subcutaneously at the ventral-most part of the nose just in front of the tip of the rostrum (Figures $1 \& 5$ ). The dense connective tissue covers the entire rostral region in front of the monkey lips, the spermaceti organ, and the junk laterally but is completely absent in the rostroventral region of the junk. A likely interpretation of this observation is that the rostral and rostroventral parts of the junk are excellent candidates for acoustic windows (terminal acoustic window) guiding the sound out of the sperm whale head as proposed by the 'bent acoustic horn hypothesis'. The longitudinal axes of the bent acoustic horn (Møhl, 2001; Møhl et al., 2003a, b) consisting of both fat bodies (spermaceti organ and junk), which form an angle of $18-20^{\circ}$ in lateral aspect, also seem to be offset from one another in the transverse plane (Figures $1 \mathrm{C}-3$ ). More specifically, reviewing the potential sound path through the fat bodies, the centre of the spermaceti organ in its rostral half does not lie in a mid-sagittal plane but is located distinctly to the right side of the animal. The caudal end of the spermaceti organ, however, fits symmetrically into the amphitheatre (Figures $1 \mathrm{C}-3$ ). Accordingly, the potential sound path in the spermaceti organ swings back from the monkey lips on the right to the centre of the acoustic mirror at the amphitheatre, continues through a ventral window in the case (connecting acoustic window; Figure 5B: CAW) slightly to the left and through the junk and finally swings back to the midsagittal plane at the terminal acoustic window (Figures $1 \&$ \& 2 ) situated at the rostroventral tip of the sperm whale nose (Figure $5 \mathrm{~B}$ : TAW).

Projected on a sagittal plane, the bent acoustic horn crucially depends on the angle between the axis of the spermaceti organ and the plane of the acoustic mirror of the frontal sac and amphitheatre, respectively. In the adult sperm whale, this angle guarantees sound reflection at the frontal sac in the direction of the junk (green line in Figure ${ }_{5} \mathrm{~B}$ ).

As discussed above the two fat bodies are largely continuous in the area of the proposed sound path (Cranford, 1999; Møhl, 2001) via fat-containing connective and muscle tissue through the connecting acoustic window in the case. In this area, where the case is lacking, the fat bodies are only separated by the interposed flat right nasal passage and its fatty muscle (Figures $1-3 \& 5$ ). At this central position, the right nasal passage, its muscle and the spermaceti organ are of a similar width (Figure $1 \mathrm{C}$ ).

The lipids of the melon in delphinids reportedly are toxic to the animal (Morris, 1986) and the same may be true for lipids in the spermaceti organ of sperm whales. Both in starved neonate and old sperm whale specimens, the spermaceti organ retains its size, volume and intrinsic pressure, implying that the wax esters are metabolically inaccessible (Madsen, 2002). Macroscopic dissection did not reveal a significant blood supply necessary for a noteworthy turnover of these fats. Thus, the fat bodies in the nasal complex of sperm whales do not serve as an energy store that can be metabolized when needed (Madsen, 2002). These facts emphasize the functionally derived character of the 'acoustic fats' in toothed whales as well as the importance of these structures for the aquatic lifestyle (e.g. echolocation).

\section{Pneumatic changes in the right nasal passage and air recycling}

Sperm whales are capable of diving to enormous depths in pursuit of their prey, which has profound effects on the volume of air available for sound production. It is still not known how these animals can produce click sounds by means of a pneumatically driven mechanism with rapidly shrinking volumes of air during dives down to more than 1000 m (Papastavrou et al., 1989; Wahlberg, 2002). In dolphins, air in the nasal complex is probably pressurized by piston-like movements of the larynx in order to drive click production (Cranford et al., 1996; Huggenberger et al., 2008). In a diving $15 \mathrm{~m}$ sperm whale with a (vital) lung capacity of approximately $750 \mathrm{l}$ at surface level (Clarke, 1978a), however, only a volume of about $7.5 \mathrm{l}$ is left at $1000 \mathrm{~m}$ depth for the production of sonar signals. It is plausible that, during dives, the animals transfer a significant amount of air from the lungs into the nasal system. However, it is not probable that sperm whales produce the air pressure to drive sound generation by movements of their larynx as suggested for dolphins and porpoises (Huggenberger et al., 2008). For this scenario diving sperm whales would need to pressurize air throughout the whole right nasal passage. In this situation, however, small quantities of air would hardly suffice phonation at the monkey lips. Thus, from an anatomical point of view, it is plausible that the pressure needed for the generation of pulsed sounds may be produced only by structures immediately associated with the right nasal passage/ monkey lip unit (Norris \& Harvey, 1972). This is in line with the observation that sperm whales can breathe and click simultaneously (Wahlberg et al., 2005).

The pulling force of the maxillonasolabialis muscle, covering the nasal complex dorsally and laterally, was estimated to be $100 \mathrm{kN}$ in adult male sperm whales (Norris \& Møhl, 1983). In this respect, the high transverse back of the amphitheatre at the rear end of the skull serves as an abutment for both the spermaceti organ and the muscles which originate here. Controlled retraction of the maxillonasolabialis muscle complex (lateral and dorsal portions) may build up considerable tension in the whole epicranial complex resulting in a compression of air in the mid and rear portion of the right nasal passage until the latter collapses (Huggenberger et al., 2014). Concomitantly, small quantities of residual air could be shifted along the right nasal passage in the direction of the monkey lips which can be used here for click generation. This process may happen rather like the squeezing of toothpaste out of a tube (from the rear to the front) and be similar to the mechanism proposed by Norris \& Møhl (1983). However, these authors (Norris \& Møhl, 1983) did not describe this mechanism in detail. Fine-tuning and the directionality of air flow to generate click sounds could be controlled by the right nasal passage muscle. Altogether it seems likely that the right nasal passage serves as an air-collecting system in which small quanta of air are forced in the direction of the monkey lips. 
In the sperm whale, according to our morphological examinations, small amounts of pressurized air, collected and conducted in the right lateral channel of the collapsed right nasal passage, can stream through the monkey lips, distributed by the system of branching thin furrows (Norris \& Harvey, 1972). These small furrows may cause the air to spread regularly over the inner surface of the nearly closed lips (Norris \& Harvey, 1972). As a result, the lips can act as two entities and clap their whole inner surfaces together. This simultaneous action should produce an even and broad pressure (sound) wave in the adjacent tissue (spermaceti organ) as a main prerequisite for the emission of high-intensity short acoustic pulses.

Coda clicks consist of high-repetition pulses which decay more slowly in intensity compared with those found in usual (echolocation) clicks (Marcoux et al., 2006; Schulz et al., 2009). Moreover, the additional pulses of echolocation clicks are lower in amplitude in relation to the first ( $\left.\mathrm{p}_{1}\right)$ pulse if recorded on-axis in comparison to off-axis recordings (Møhl et al., 2003b; Zimmer et al., 2005a; Antunes et al., 2010). According to the Norris \& Harvey theory (1972), the higher number of successive pulses in coda clicks of sperm whales (in comparison to echolocation clicks) are generated by additional reflections between the two acoustic mirrors, the distal sac and the frontal sac (Cranford, 1999; Møhl, 2001; Madsen et al., 2002a; Møhl et al., 2003a, b). Therefore it is likely that the right nasal passage may be the control device for the acoustic mechanism to switch between two modes of sound generation (Huggenberger et al., 2014). If the right nasal passage contains a small volume of air at its connecting acoustic window it would reflect and thus trap most of the energy within the spermaceti organ. Due to the impedance mismatch between tissue and air only part of the sound energy is transmitted via the junk into the water so that multiple cycles of pulses of decaying intensity are generated (coda click generation). In contrast, the local collapse of the right nasal passage at the connecting acoustic window, e.g. due to the shift of air in the direction of the monkey lips by means of muscle action or water pressure, may allow most of the sound energy of the initial pulse to pass into the junk. Thus, additional reflections (pulses) are fewer and less energetic (echolocation click) (Huggenberger et al., 2014).

As mentioned above, the pressure of the air stream through the monkey lips may be generated by muscle action of the maxillonasolabialis muscle. If only a relatively small volume of air is present in the right nasal passage, the pull of the maxillonasolabialis muscle should cause, at least in part, a collapse of the mid and rear portions of this nasal passage, i.e. in the area of the connecting acoustic window (Huggenberger et al., 2014). In this case, most of the sound energy should enter the junk in the first pulse $\mathrm{p}_{1}$ (echolocation click). However, if the right nasal passage is filled with a higher amount of air, this slight bending should create air pressure for phonation even without a collapse of the passage (coda click generation). Fine tuning of the air distribution may be provided by the right nasal passage muscle which accompanies the right nasal passage along most of its length (Figures 1 3 \& 5) (Clarke, 1978b; Huggenberger et al., 2014). To switch between the generation cycles of different click types (echolocation clicks and coda clicks) air may be transported from the right nasal passage to the nasopharynx and vice versa by piston-like movements of the larynx as was presumed for other toothed whales as a general mechanism in sound production (Cranford et al., 1996; Møhl et al., 2003b).
In the collapsing right nasal passage during diving, residual air must be transported forward to the monkey lips to feed the sound generation process for echolocation clicks. According to our morphological examinations, the right nasal passage is equipped with 'residual channels' at its lateral contours which may conduct air in the pressurized tract and persist even when its central part is collapsed (Figure $2 \mathrm{~B}$ ). As a result, even small amounts of pressurized air, collected and conducted in the lateral channels of the collapsed right nasal passage, can flow at high velocities through the monkey lips. Partial sound reflections at these air-filled lateral channels of the collapsed right nasal passage may be the reason for the fact that echolocation clicks show additional pulses in higher amplitude when recorded off-axis in comparison to on-axis recordings.

The function of the right nasal passage as an acoustic interface also implies that the idea of the spermaceti organ as a buoyancy device for diving is questionable: Clarke (1970, 1978a, 2003) hypothesized that the specific weight of the spermaceti wax can be changed to adjust the buoyancy of a sperm whale either by cooling the spermaceti organ due to the ingestion of sea water into the right nasal passage or by heating it via blood vessels within the case. However, due to the poor angioarchitectonics along the spermaceti organ (no obvious blood supply within most of the case), this hypothesis is unlikely since, under such conditions, the heating of large amounts of fat would certainly be cumbersome and timeconsuming. Moreover, the unique structure of the right nasal passage can be explained satisfactorily by its acoustic function and not as a device for cooling the spermaceti organ. The argument that sperm whales do not usually click at the beginning of deep dives (Whitehead, 2003; Teloni et al., 2005), when seawater is presumed to be in the right nasal passage to cool the spermaceti organ (Clarke, 1970), is illogical given the fact that their food mainly consists of squid found at even greater depths (Whitehead, 2009).

The mechanism of phonation with changing amounts of air in the right nasal passage can explain the differences between coda clicks and echolocation clicks (Huggenberger et al., 2014) and how air is pressurized in this passage without the help of larynx-associated muscles (Wahlberg et al., 2005). It is not clear, however, how other sperm whale vocalizations such as creaks, slow clicks or trumpet sounds (see Table 1) are generated. Moreover, it is unknown which structures and/or tissues may serve as additional devices to focus echolocation clicks more than coda clicks. However, it is plausible that the sound beam focus is modulated by other air spaces and/or tissue interfaces. More specifically, it can be speculated that the actual shape of the distal and frontal sacs, which depends on their volume and thus on muscle tonicity and air pressure, respectively, may play an important role in focusing click sounds. Thus, changes in the amount of air in the frontal sac could alter the directionality of the emitted sound beam:

(a) For more focused beams (echolocation clicks), this sac should decrease in volume, approximating the shape of the rounded back of the amphitheatre, then being reminiscent of a parabolic mirror (Figure $7 \mathrm{~A}$ ).

(b) For less directional beams (coda clicks), this sac may contain larger air volumes bulging out rostrally (Figure $7 \mathrm{~B}$ ). The latter situation would also be consistent with the extended pulse structure of coda clicks (Schulz 


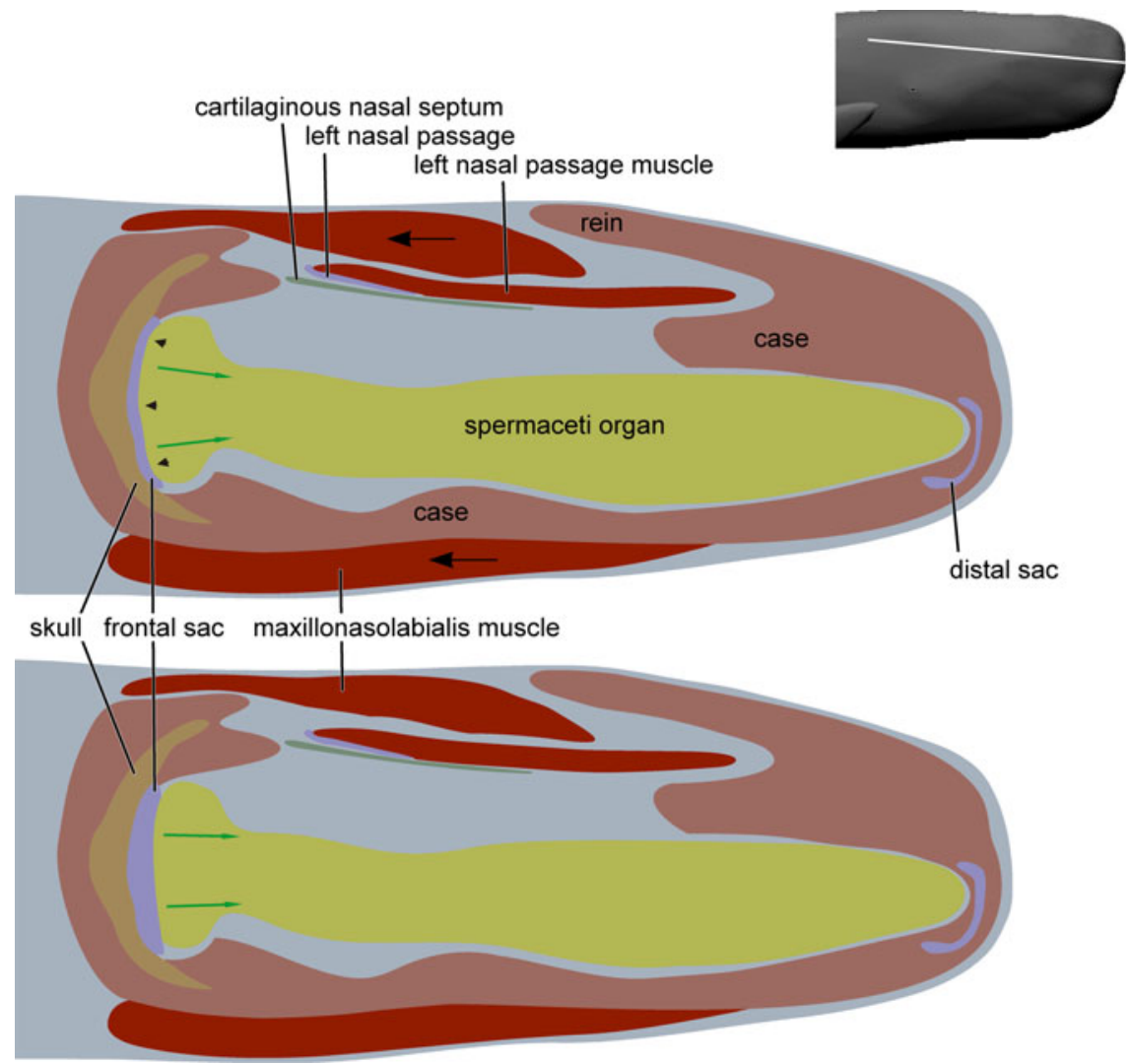

Fig. 7. Horizontal view of the reconstructed sperm whale head (tip of nose facing right; for sectional level see inset) showing the proposed mechanism of echolocation click focusing in the adult sperm whale head (A). Green arrows indicate the proposed direction of the sound reflected at the frontal sac. Large black arrows stand for the pull of the maxillonasolabialis muscle which compresses the air within the frontal sac and gives a more rounded shape to the acoustic mirror (black arrowheads). In contrast, a relaxed muscle and thus an inflated air sac may generate a flat acoustic mirror (B) creating a less focused sound beam (coda click). For colour code see Figure 1.

et al., 2009) because the two reflective surfaces (rostral and caudal walls of the frontal sac) would be further away from each other.

Whenever the strong maxillonasolabial muscle contracts to shift air along the right nasal passage in the direction of the monkey lips, the air in the frontal sac should be pressurized simultaneously (Figure 7). The fluid-filled bubbles in the caudal wall of the frontal sac may have to withstand strong pressure exerted on the spermaceti organ in an axial direction but should keep an intrinsic 'reticular' system of air spaces (Norris \& Harvey, 1972). By this they may prevent the total collapse of the frontal sac and thus maintain the function of the caudal acoustic reflector (Norris \& Harvey, 1972). The fact that the mean diameter of the bubbles in the frontal sac is shorter than the wavelength of the peak frequency of adult sperm whale sounds may be correlated with the function of the sac as an acoustic mirror. Such bubbles were found in adult animals and the larger sperm whale calf (Calf 2) but not in the smaller specimen investigated (Calf 1 ). Instead, in this younger animal, the caudal epithelium of the frontal sac exhibits pinholes (not shown in figures) which may represent an early developmental stage of the epithelial specialization. Moreover, this fact may point out that the epithelial bubbles are adaptations to the physical conditions in deep-diving with shrinking volumes of air because young sperm whales do not dive as deep as adults (Papastavrou et al., 1989); they stay at the surface and are 'baby-sat' by other adult females while their mothers hunt at greater depths (Gordon, 1987; Whitehead, 1996; Madsen et al., 2003).

After a sound generation cycle, the 'used' air may be recycled directly from the distal sac via backward suction through the monkey lips into the right nasal passage caused by the contraction of associated muscles. Tension of only the dorsal portion of the maxillonasolabialis muscle should open the monkey lips while contractions of the right nasal passage muscle may open the volume of the nasal tract. However, the potential for a circular pattern of air transport in the nose of a sperm whale (Norris \& Harvey, 1972) is theoretically given since the left nasal passage and right nasal passage are interconnected via the vestibulum of the blowhole and the distal sac rostrally (Figure 1) and via the inner nasal openings (choanae) caudally (Norris \& Harvey, 1972). This configuration would allow continuous air flow in one direction through the right nasal passage, the monkey lips, distal sac, vestibulum, left nasal passage, bony nostrils, the nasopharyngeal space and back to the right nasal passage. This possibility seems intriguing but may only fit the situation in a non-diving whale: the hydrostatic pressure during diving should compress the resident air volume to such a degree that a direct recycling from the distal sac through the monkey lips into the right nasal passage is more likely. The latter recycling pattern, reciprocal to the air movement during sound generation, is also seen in dolphins (Norris et al., 1971; Norris, 1980). 


\section{Sexual selection}

The toothed whale suborder shows a lot of functional equivalence across the structures of the epicranial complex. This is supported by accumulated evidence from visual inspection (Norris et al., 1971; Norris, 1980; Ridgway et al., 1980), manual palpation (Amundin \& Andersen, 1983; Ridgway \& Carder, 2001), high-speed video endoscopy in dolphins (Cranford, 2000; Cranford et al., 2011), the generation and examination of artificial sounds in dead animals (Møhl, 2001; Møhl et al., 2003a) as well as the analysis of acoustic behaviour (Wahlberg, 2002; Zimmer et al., 2005a, b; Beedholm \& Møhl, 2006). Altogether this implies that such structures in the epicranial complex are specific for the toothed whale sound generation and emission system. Accordingly, Cranford (1999) concluded that, in the sperm whale, the function of the nose is similar to that in other toothed whales but that it may have reached its immense size in response to a combination of selective pressures, most notably those associated with feeding ecology (midrange echolocation) and sexual selection.

The impressive dimorphism of the nasal complex in sperm whales (Nishiwaki et al., 1963; Berzin, 1972; Nakamura et al., 2013) was interpreted by Cranford (1999) in terms of acoustic sexual selection since larger males have longer inter-click and inter-pulse intervals than smaller animals which is in agreement with the theory of Norris \& Harvey (1972). Because there is some evidence for female choice in sperm whales (Whitehead, 2003), males with longer inter-pulse intervals should be more attractive for females.

Another hypothesis by Carrier et al. (2002) interprets the hypertrophied nose of sperm whales as a potential weapon specialized in male-male aggression. In this respect, the use of the spermaceti organ as a battering ram (Carrier et al., 2002; Lusseau, 2003) is not plausible: the sonar system is so important for the survival of sperm whales that these animals would probably not risk damage to this vital device in regular competitive fights. Although the rostral part of the spermaceti organ may be protected by thick connective tissue of the case, the sound generator (monkey lips) at its rostral tip would be in an exposed position during such fights. Furthermore, neither in the skull nor in the spine are there strong skeletal structures such as bony bracing elements, which could divert or absorb the mechanic forces of ramming.

\section{DNTDGENETIC AND PHYLOGENETICIMPLICATIONS}

In contrast to other cetaceans, sperm whales have two long nasal cartilaginous structures which do not ossify even in old specimens:

(a) The long rostral cartilage (cartilaginous rostrum), which is the centre of the rostrum in all adult cetaceans (Klima, 1990, 1999).

(b) The nasal roof cartilage, which is typical for the adult sperm whale and extends diagonally through their nasal complex (Figures 1-3 \& 5) (Flower, 1867; Behrmann \& Klima, 1985; Klima, 1990, 1999; Huggenberger et al., 2006).

The nasal roof cartilage of the sperm whale running along the left nasal passage was described first by Behrmann \& Klima (1985). It is interesting to note that, whereas the rostral cartilage consists of hyaline cartilage, the nasal roof cartilage is an intermediate between hyaline and elastic cartilage (Klima et al., 1986a, b; Huggenberger et al., 2006). In view of its delicateness, the nasal roof cartilage cannot support the nasal complex as a whole but seems to serve the operation of the left nasal passage during respiration (Huggenberger et al., 2006). Because the nasal roof cartilage is equivalent to the tectum nasi and the dorsocaudal part of the septum nasi of late embryonic and foetal stages (Behrmann \& Klima, 1985; Klima, 1999) it illustrates the original midsagittal plane of the toothed whale bauplan before the extreme modification of the sperm whale head came about: during evolution, it was obviously displaced to the left by the increasing size of the spermaceti organ (Cranford et al., 1996). According to the developmental pattern of the nasal roof cartilage, the cetacean suborder can be divided into at least three groups: baleen whales, sperm whales (physeterids) and the remaining non-physeterid toothed whales. In this context, the nasal roof cartilage of sperm whales resembles the situation in baleen whales, and both these groups differ from the non-physeterid toothed whales (Klima, 1995, 1999). These findings have been interpreted in favour of a closer relationship of sperm whales with the baleen whales than with the remaining toothed whales (Klima, 1999) in accordance with the analysis of Milinkovitch (1995) which was based on genetic studies. In the meantime, a plethora of papers (old and new) have characterized the sperm whales as genuine toothed whales which, however, seem to have diverted early from the toothed whale clade (Barnes et al., 1985; Heyning, 1989; Cranford et al., 1996; Berta \& Sumich, 1999; Fordyce \& de Muizon, 2001; Price et al., 2005; Fordyce, 2009a, b; Geisler et al., 2014).

The two cartilaginous structures in the forehead of the adult sperm whale both have important implications for the reconstruction of the development and evolution of their nose. The rostral cartilage was described as an ontogenetic 'pacemaker' in the formation of the cetacean rostrum because, as a central structure, it seems to drive the elongation of the rostrum by means of strong cartilaginous tissue proliferation and thus longitudinal growth, which is followed at some distance by the much slower growth and elongation of the dermal premaxillary, maxillary and vomer bones (Klima et al., 1986a, b; Klima, 1987, 1999).

At least as important for the interpretation of the cetacean rostrum is the nasal roof cartilage. In the mature condition, the shape of this upper cartilage and its topographical relations with neighbouring structures are unparalleled throughout the animal kingdom. This cartilage was interpreted first in detail by Milan Klima (1990). Therefore and because of the heuristic value of this structure for the understanding of the sperm whale nose (see below) it is referred to as 'Klima's cartilage'.

In the terrestrial ancestors of the cetaceans among the Cetartiodactyla as well as in the first Archaeoceti, the nostrils were still in a more or less terminal position (Gingerich et al., 2001; Thewissen et al., 2001; Fahlke et al., 2011). In contrast, in more modern cetaceans, these nasal openings were shifted backward along the mid-line of the upper jaw to a position just before the brain case. This shift was part of a total reorganization of the nasal region accompanied by the elongation and broadening of the upper jaw bones rostral and caudal to the bony nostrils, covering the bony elements of the forehead (telescoping) (Miller, 1923). Concomitantly, the nasal passages were rotated about $90^{\circ}$ upward and backward so that in all extant non-physeterid toothed whales they 
A

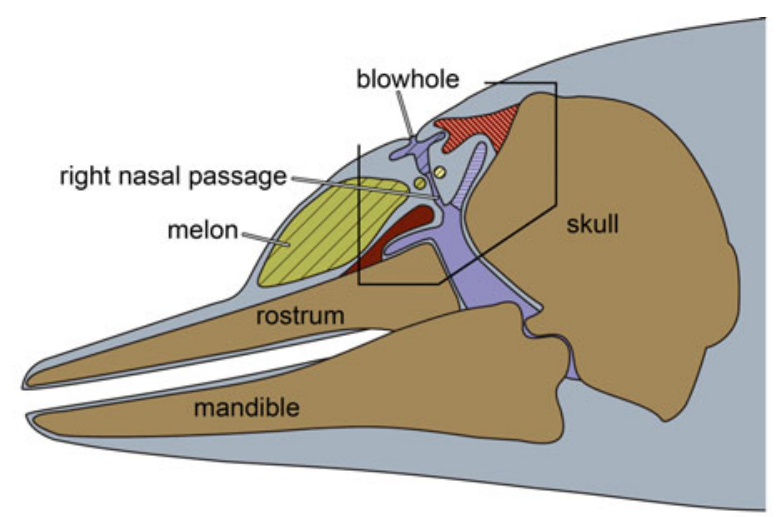

B
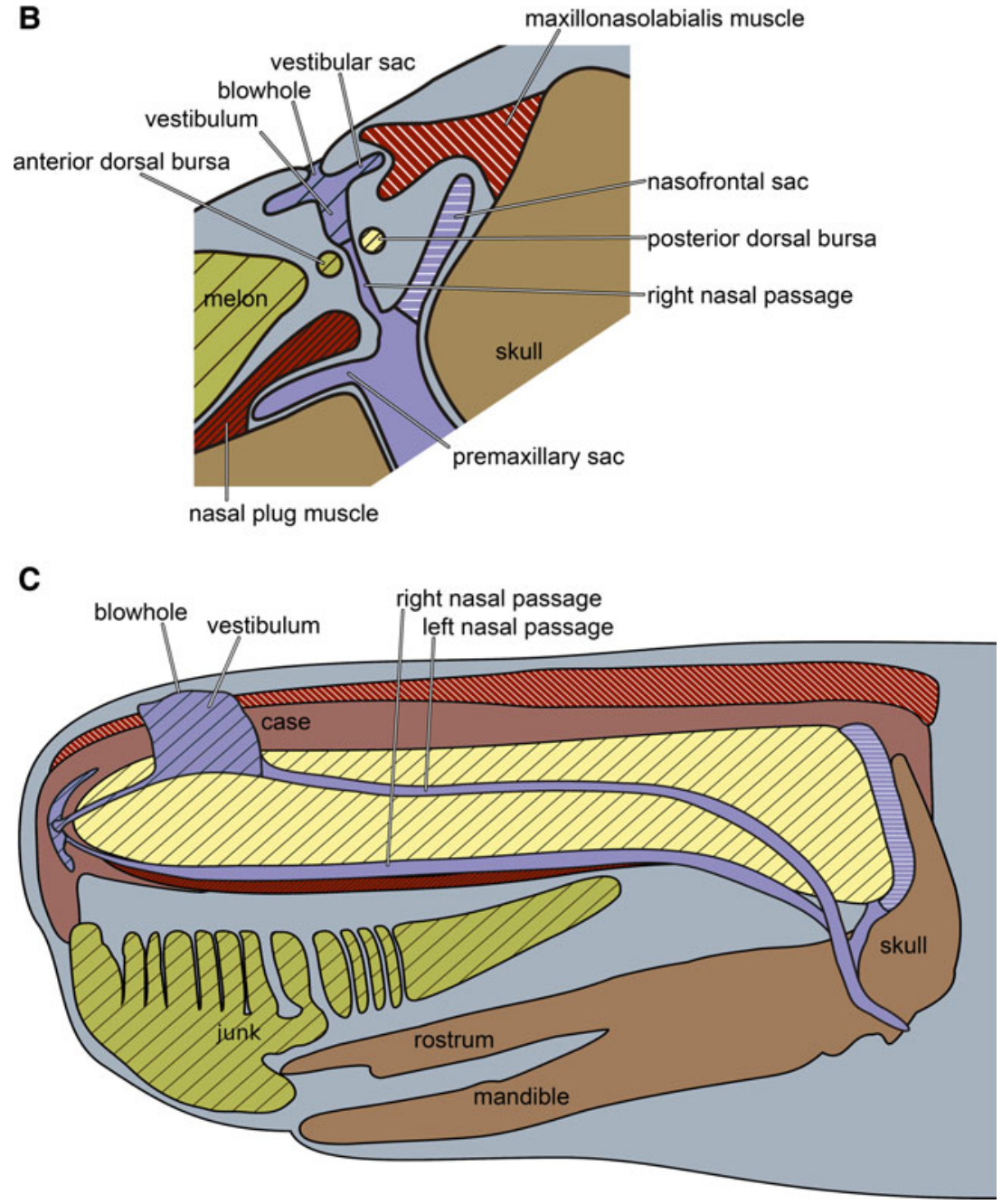

Fig. 8. Comparison of delphinid and sperm whale heads: schematic parasagittal views (right side of head) of a delphinid (A, B) and sagittal projection of an adult sperm whale head (C). The boxed area in (A) is shown at higher magnification in (B). Proposed homologous structures within the nasal complex are given in the same colouring and hatching: purple and black hatching, vestibulum; purple and white hatching, right (naso-) frontal sac; red and white hatching, maxillonasolabialis muscle; red and black hatching, nasal passage muscle/nasal plug muscle; light yellow and black hatching, right posterior dorsal bursa/ spermaceti organ; dark yellow and black hatching, melon/junk; shade of body in grey.

stand nearly perpendicular to the skull base (Figure $8 \mathrm{~B}$ ) (Klima, 1987). In toothed whales, generally, the reorganization of the nose led to the reduction of the peripheral olfactory system (Oelschläger \& Buhl, 1985a, b; Oelschläger \& Kemp, 1998; Oelschläger \& Oelschläger, 2002, 2009; Oelschläger, 2008; Oelschläger et al., 2010) and left over respiratory tubes secondarily equipped with accessory air sacs and used for the generation and emission of sonar signals (Figure 8A) (Norris, 1980; Cranford, 2000). However, whereas in most extant toothed whales, the blowhole and the bony nostrils are situated immediately before the brain case of the skull, the sperm whale shows a highly derived situation. Due to the development of the spermaceti organ as a hypertrophied 'new' acoustic fat body out of the 
small right caudal dorsal bursa (see below; Figure 8A, B) (Cranford et al., 1996), the blowhole with the phonetic apparatus (monkey lips) was shifted far rostrally. By that, the nasal passages connecting the blowhole and the bony nostrils were strongly elongated. Concluding from all this, the course of Klima's cartilage throughout the epicranial complex stands for the evolutionary shift of the blowhole (with the phonetic apparatus) in a secondary terminal position. This course can be seen as a trajectory of this process which, in principle, is repeated during the foetal period of sperm whale development (Klima, 1999).

\section{Homologies in toothed whale forehead structures}

Interestingly, there is no aquatic mammal that evolved a nasal complex with the external openings on the vertex of the forehead in the way cetaceans did. However, during the Triassic era there were crocodile-like phytosaurs (Phytosauridae, Reptilia) that were probably adapted to an at least semiaquatic freshwater lifestyle. As a convergence to the situation in cetaceans, their nasal passages were also positioned far caudally and in front of the brain case. In addition, the bony nasal openings of phytosaurs were on top of a prominence and thus in most species on the most dorsal point of the skull (Mazin, 2001; Britannica Online Encyclopedia, 2013).

Within the Mammalia, it seems that the modifications of the nasal design and the corresponding osteological transformations were most pronounced in cetaceans (Frey et al., 2007). Accordingly, the homologization of nasal structures in toothed whales with those in non-cetaceans is difficult. Murie (1874) suggested that dolphin nasal air sacs may be homologous to the nasal diverticula of the Saiga antelope (Saiga tatarica). Saiga antelopes have an extended vestibulum nasi with lateral recesses that may be homologous to the nasal sacs of the dromedary (Camelus dromedarius) (Clifford \& Witmer, 2004). In contrast, Purves \& Pilleri (1978) hypothesized that only the vestibular sacs are homologous to the vestibulum nasi and the anterior part of the nasal tract in terrestrial mammals. The nasofrontal sacs can be homologized with the frontal and ethmoid sinuses of terrestrial mammals (Purves \& Pilleri, 1978). Besides it was speculated that the three floors of nasal air sacs (vestibular, nasofrontal, and premaxillary sacs) represent the three nasal segments (upper, middle and lower) of the nasal cavity in terrestrial mammals (Agarkov et al., 1979; Solntseva \& Rodionov, 2012).

Concerning the comparative anatomy of toothed whales, there were several attempts to homologize the nasal structures. Schenkkan \& Purves (1973) hypothesized that the monkey lips of physeterids are homologous to these lips in the right nasal passage of other toothed whales. Some years later, Cranford et al. (1996), reviewed the discussion on homologies in the toothed whale nasal complex and concluded that the spermaceti organ in the sperm whales Physeter and Kogia spp. is probably homologous to the right caudal dorsal bursa of non-physeterid toothed whales. This fatty structure shows the same topographic relationships in all toothed whales. Here, it is located in the caudal wall of the right nasal passage and behind the caudal monkey lip (the dorsal monkey lip in the sperm whale). This hypothesis implies that the spermaceti organ did not develop de novo, as had been suggested previously (Heyning, 1989), but evolved with the exceptional hypertrophy of the right side of the forehead in sperm whales (Cranford et al., 1996). Accordingly, the so-called 'case' that contains the sperm whale's spermaceti organ is probably homologous to the connective tissue pouch, which encases the acoustic fat of the posterior bursa in dolphins and porpoises (Cranford et al., 1996).

In the adult sperm whale, the right side of the head dominates so much over the corresponding structures on the left that the centres of right structures are situated nearly in the mid-sagittal plane (Figures $2 \& 3$ ). This results in a marked but 'balanced' asymmetry (spermaceti organ slightly more to the right-hand side and, as a consequence, the junk slightly more to the left; see Figures $1 \mathrm{C} \& 2$ ) which is nearly indiscernible in external view (exception: the position of the blowhole, which is shifted to the left).

The melon and the junk, respectively, are also in the same relative topographical position within the head and may be homologous (Cranford et al., 1996): in both physeterids and non-physeterids these fat bodies rest on the bony rostrum anterior to the nasal passages. The loose connective tissue of the junk in the sperm whale, interspersed with numerous fatty lenses, may not only serve as an impedance transformer for outgoing sound beams but also as a basis for the suspension of the spermaceti organ.

Although in dolphins both pairs of monkey lips seem to be active in sound production, there is a beginning specialization as to their functional properties. Either of the left and right sound generators may produce different peak frequencies within a single click (Cranford et al., 1996, 2011; Cranford, 2000) or, as shown for delphinids (Tursiops truncatus, Pseudorca crassidens) and a porpoise (Phocoena phocoena), only the right side was used to generate a single click (Madsen et al., 2010, 2013). The delphinids tested by Madsen et al. (2013) used the left monkey lips only to produce whistles. In sperm whales, only the right pair of monkey lips has been retained whereas the left pair has vanished. The interpretation, that the sperm whale exhibits an extreme in the functional segregation of the two nasal tracts, helps to explain why asymmetry in toothed whales is mainly restricted to the epicranial complex and to the skull roof. Ventral aspects of the skull do not exhibit such a degree of asymmetry (Flower, 1867; van Beneden \& Gervais, 1868; MacLeod et al., 2007; Mead \& Fordyce, 2009). In the most extreme skulls of toothed whales (Kogia spp.), asymmetry in the ventral skull is restricted to the shape and size of the choanae and bony nasal tubes and to the vomer element, altogether the area of the nasal skull (Duguy, 1995a, b; MacLeod et al., 2007).

From the fossil record it appears that the facial skulls of early cetaceans were bilaterally symmetrical (Fordyce \& de Muizon, 2001) or slightly asymmetrical (Fahlke et al., 2011). The Archaeoceti, fully adapted to aquatic life, still had subterminal bony nostrils and paranasal sinuses. In these animals, the nostrils had already started to migrate caudalward, leading to more efficient surfacing for breathing between dives. The midline sutures of their skulls were slightly distorted clockwise (Fahlke et al., 2011) but the skull bones of both sides were equal in size and in position relative to the midline suture, as is the case in all fossil and extant baleen whales (van Beneden \& Gervais, 1868; Heyning, 1989; Heyning \& Mead, 1990). The first toothed whales of the Oligocene with their caudal position of the bony nostrils and a facial depression (indicative of a melon and thus the 
ability to echolocate (Geisler et al., 2014)) started to shift the bony nares slightly to the left by means of a stronger broadening of skull roof elements on the right (and to twist the area clockwise in dorsal view) (Fordyce \& de Muizon, 2001). This asymmetry of the skull roof brought the right bony naris and its monkey lips into a more axial position, a fact which could be related to most non-physeterid toothed whales. In sperm whales, this primary bilateral asymmetry was intensified by the extreme expansion of the right posterior dorsal bursa of toothed whales into the spermaceti organ and the extension of this thickened fat body to the left into a nearmidsagittal position (Cranford et al., 1996). In extant sperm whales, the right anterior dorsal bursa and both left dorsal bursae seem to have been lost.

Mead (1972; Cranford et al., 1996) recognized the unpaired vestibulum between the blowhole and the monkey lips as a common entity in delphinids that becomes highly modified in some toothed whale groups. This vestibulum in delphinids as well as in phocoenids has paired outpockets, termed vestibular sacs, with their openings located just dorsal to the monkey lips (Mead, 1975; Curry, 1992; Cranford et al., 1996; Huggenberger et al., 2009). The distal sac of sperm whales is in a similar relative position to the monkey lips as the right vestibular sac in dolphins. A similar situation is found in Kogia spp.: Kogia's vestibular sac is in the same position to neighbouring structures such as the blowhole, the vestibulum and the monkey lips. In Kogia spp., the vestibular sac is only present on the right-hand side (as in the sperm whale) but characterized by a central cushion of tough connective tissue, the function of which cannot be fully explained yet (Schenkkan \& Purves, 1973; Cranford et al., 1996; Huggenberger, 2004). According to these similarities in their relative position, it is likely that the vestibulum represents a unified (apomorphic) character of the toothed whales as a whole, and that its outpockets formally called vestibular sacs in delphinids, phocoenids and Kogia spp. as well as distal sac in Physeter are indeed modifications of the vestibulum (Figure 8).

The vestibulum of the toothed whale blowhole should not be equated with the vestibulum nasi of non-cetacean mammals. Concluding from the shape of the facial skull, i.e. the position of the bony nasal openings (aperturae nasi osseae) and the relative position of the nasal complex, by the soft parts of the toothed whale nose with its nasal air sacs and fat bodies should be homologous to the vestibulum nasi of other mammals. Both structures, the toothed whale nasal complex and the mammalian vestibulum nasi are located superficial of the aperturae nasi osseae. Accordingly, toothed whales have evolved the most extraordinary and probably the most complex vestibulum nasi among mammals. This interpretation, however, needs to be verified by further investigations.

The caudal right nasofrontal sac in non-physeterid toothed whales (Lawrence \& Schevill, 1956; Mead, 1975; Heyning, 1989; Cranford et al., 1996; Huggenberger et al., 2009), the (right) nasofrontal sac in Kogia spp., and the frontal sac in the sperm whale all show the same relative position to the fat bodies (caudal dorsal bursa and spermaceti organ, respectively) and to the skull. Therefore, it appears that these (naso-) frontal sacs are also homologous structures found throughout the Odontoceti (Figure 8).

Because of the morphogenetic distance between sperm whales (physeterids) and other toothed whales (Fordyce \& de Muizon, 2001; Price et al., 2005), it is difficult to derive or homologize single components of the maxillonasolabialis muscle complex across the toothed whales. However, it is very likely that, as a whole, the epicranial muscles in all the toothed whales go back to a common ancestral configuration thus the earliest toothed whales showed the same general facial configuration (i.e. the supraorbital process of the maxilla formed the origin of a large volume of facial muscles) (Fordyce \& de Muizon, 2001; Geisler et al., 2014) as modern dolphins. In the case of the sperm whale, these muscles reflect the profound phylogenetic modifications of the epicranial complex in this species which led to a unique situation with respect to that in terrestrial mammals (Oelschläger, 2008; Oelschläger et al., 2010). In parallel to the secondary rostral shift of the blowhole to the dorsal tip of the sperm whale snout, the course of the muscle fibre bundles from the margins of the skull roof to the blowhole has changed from a more concentric (radial) orientation of up to six muscle layers in dolphins and porpoises (Lawrence \& Schevill, 1956; Mead, 1975; Heyning, 1989; Huggenberger et al., 2009) to a more longitudinal orientation of a single powerful muscle (maxillonasolabialis muscle) in sperm whales. Besides the specific course of Klima's cartilage from the bony nares to the blowhole area this is another hint for the secondary shift of the external nasal opening into a terminal position during the ontogenesis and evolution of sperm whales.

Moreover, it seems that the nasal passage muscles found in sperm whales are homologous to the nasal plug muscles in other toothed whales due to their close topographical relationship: in all toothed whale groups examined so far, each of these muscles is located rostral to the associated nasal passage (rostro-ventral in the sperm whale due to the secondary turn-over of the nasal passages in the rostral direction) and acts as a dilator of the latter (Lawrence \& Schevill, 1956; Mead, 1975; Heyning, 1989; Huggenberger et al., 2009). Accordingly, the musculature in the epicranial complex of the sperm whale is likely homologous to that of dolphins innervated by the facial nerve (Mead, 1975; Rauschmann, 1992; Rommel et al., 2002, 2009; Rauschmann et al., 2006; Huggenberger et al., 2009). In contrast to the situation in non-cetacean mammals, this cranial nerve runs without significant ramification from the tympanoperiotic complex to and below the orbita, turns upward around the lateral margin of the skull roof via the antorbital notch, and then ramifies strongly in order to innervate the blowhole musculature (Rauschmann, 1992; Rommel et al., 2002, 2009). In the sperm whale, not only the diameter but also the number of axons of the facial nerve is much higher than in other toothed whales investigated so far, and also in comparison to baleen whales of the same body size (Oelschläger \& Kemp, 1998; Oelschläger \& Oelschläger, 2002, 2009). This correlates, on the one hand, with the extreme absolute and relative size of the head and the nasal musculature and, on the other hand, with the fact that baleen whales do not echolocate and possess a much less developed nasal area (no epicranial complex).

These proposed homologies of epicranial structures across the toothed whale suborder (Figure 8) imply that the ancestors of all extant toothed whales were echolocators. This assumption corresponds with the fact that the asymmetry of the nasal complex in toothed whales shows the same general pattern (Ness, 1967) and that all toothed whales from their earliest origins show evidence for 
Table 2. Proposed new nomenclature of toothed whale nasal structures.

\begin{tabular}{ll}
\hline Proposed nomenclature & Old nomenclature \\
\hline Corpus adiposum nasalis anterior & Anterior dorsal bursa (anterior bursa cantantis) (Cranford et al., \\
Corpus adiposum nasalis posterior & Posterior dorsal bursa (posterior bursa cantantis) (Cranford et al., \\
& 1996) or spermaceti organ \\
Corpus adiposum nasalis terminalis & Melon and junk \\
Musculus maxillonasolabialis (Huber, 1934; Huggenberger et al., & Muscles inserting in the melon and around the soft nasal passages \\
2009) & \\
Musculus maxillonasolabialis, pars valvae nasalis ventralis & Nasal plug muscle \\
Saccus nasalis nasofrontalis & Nasofrontal sac \\
Saccus nasalis praemaxillaris & Premaxillary sac \\
Saccus nasalis vestibularis & Vestibular sac \\
Valva nasalis dorsalis (Rodionov \& Markov, 1992) & Lip of blowhole \\
Valva nasalis intermedia & Monkey lips \\
Valva nasalis ventralis (Rodionov \& Markov, 1992) & Nasal plug \\
Vestibulum nasi superficialis* & Vestibulum of blowhole \\
\hline
\end{tabular}

*The toothed whale nasal complex as a whole seems to be homologous to the vestibulum nasi of non-cetacean mammals. Thus, the vestibulum of the toothed whale blowhole may be only the superficial part of the vestibulum nasi of non-cetacean mammals (see 'Homologies in toothed whale forehead structures'). The proposed nomenclature includes only terms of structures typical for odontocetes.

echolocation (Fordyce \& de Muizon, 2001; Rauschmann et al., 2006; Geisler et al., 2014). These findings, in turn, imply that the active sonar system has evolved only once and that the hypertrophy of the sperm whale nasal complex represents an adaptation of the design of the toothed whale sound generation apparatus to mid-range echolocation in the open ocean.

\section{Nomenclature of nasal structures in toothed whales}

So far, there is no consensus for a valid taxonomy of nasal structures in toothed whales. Most terms of structures are based on generic names proposed in classical papers, sometimes in languages others than English (Sibson, 1848; Flower, 1867; van Beneden \& Gervais, 1868; Pouchet \& Beauregard, 1885; Kükenthal, 1893; Boenninghaus, 1903; Raven \& Gregory, 1933; Lawrence \& Schevill, 1956; Moris, 1969; Norris \& Harvey, 1972, 1974; Norris, 1980). For instance, the terms 'junk' and 'spermaceti organ' as well as 'case' were probably coined a long time ago by whalers (Scammon, 1874) who could not assess the comparative anatomical and functional implications of these tissues. Moreover, the term 'dorsal bursa' (Cranford, 1988) is misleading because these fat bodies (corpora adiposa) do not resemble a mammalian bursa (bursa synovialis).

The nasal muscular system is a derivative of the mammalian facial muscles (M. maxillonasolabialis; Huber 1934; Huggenberger et al., 2009) innervated by the seventh cranial nerve. However, not much is known about the origin and affiliation of functional units in different toothed whale species. A homologization of single muscular units of dolphins with those of terrestrial mammals is completely lacking. As a consequence, the nomenclature is problematic. So far, e.g., there is still no name for the nasal plug muscle.

In order to propose a valid nomenclature for nasal structures in toothed whales according to common rules (World Association of Veterinary Anatomists, 2012) the terms of structures common to most toothed whales (see 'Homologies in Toothed Whale Forehead Structures') are listed in Table 2.

\section{ACKNOWLEDGEMENTS}

We cordially thank Sam H. Ridgway (US Navy Marine Mammal Program, San Diego, CA, USA) and Ted W. Cranford (University of Southern California, San Diego, CA, USA) for the donation of neonate sperm whale material. Robert L. Brownell Jr. and William B. Perrin (Southwest Fisheries Science Center, National Marine Fisheries Service, San Diego, CA, USA) are thanked for making possible the dissection of a sperm whale neonate at their facilities. We are grateful to Georg Matjasko (Institute of Anatomy III, Dr Senckenbergische Anatomie, Frankfurt am Main, Germany) for his help in preparing the cryosections. Thomas J. Vogl and the staff of the Institute for Diagnostic and Interventional Radiology (Medical Faculty, Johann Wolfgang Goethe University, Frankfurt am Main, Germany) are thanked for their enormous help in the capture of MRI and CT data sets of neonate sperm whale material. Tadasu K. Yamada (National Museum of Nature and Science, Tokyo, Japan) kindly provided photographic material of a sperm whale calf head. We cordially thank Volker Barth and Holger Karsten (Anthro-Media, Berlin, Germany) for their kind help in reconstructing the sperm whale head. Our sincere thanks go to Jutta S. Oelschläger (Frankfurt am Main, Germany) for delicate graphical work and to Peter T. Madsen (University of Arhus, Denmark), Magnus Wahlberg (Fjord \& Bælt and University of Southern Denmark, Kerteminde, Denmark) and Bertel Møhl (University of Århus, Denmark) for helpful discussions and reviewing an earlier version of this manuscript. The senior author (H.H.A.O.) is indebted to Ted Cranford for the unique opportunity to work with him on his sperm whale material. John C. Goold and Lynda L. Goold kindly provided detailed measurements of a skull of an adult sperm whale bull. We thank James G. Mead and Charles W. Potter (National Museum of Natural History, Smithsonian Institution, Washington, DC, USA) for the opportunity to study toothed whale skulls under their care. The continuous support of our work by Jörg H. Stehle (Institute of Anatomy III, Dr Senckenbergische Anatomie, Frankfurt am Main, Germany) is gratefully acknowledged. 


\section{FINANCIAL SUPPDRT}

This project depended heavily on the financial support of the junior author (S.H.) by a postgraduate scholarship of the Johann Wolfgang Goethe University, Frankfurt am Main, Germany and the German Academic Exchange Service (DAAD). We cordially thank the Dr Senckenberg foundation in Frankfurt am Main, Germany, for generously sponsoring our work on whales and dolphins over many years.

\section{REFERENCES}

Agarkov G.B., Khomenko B.G. and Manger A.P. (1979) Functional morphology of cetaceans. (Cited after Solntseva and Rodionov, 2012). Kiev: Naukova Dumka.

Amundin M. and Andersen S.H. (1983) Bony nares air pressure and nasal plug muscle activity during click production in the harbour porpoise, Phocoena phocoena, and the bottlenosed dolphin, Tursiops truncatus. Journal of Experimental Biology 105, 275-282.

André M. (2009) The sperm whale sonar: monitoring and use in mitigation of anthropogenic noise effects in the marine environment. Nuclear Instruments and Methods in Physics Research Section A: Accelerators, Spectrometers, Detectors and Associated Equipment 602, 262-267.

André M., Johansson T., Delory E. and van der Schaar M. (2007) Foraging on squid: the sperm whale mid-range sonar. Journal of the Marine Biological Association of the United Kingdom 87, 59-67.

Anthro Media (2008) Pottwal Ahoi! Mit Moby Dick auf Tiefseetauchgang. Television documentary, ARTE, 2 September 2008

Antunes R., Rendell L. and Gordon J. (2010) Measuring inter-pulse intervals in sperm whale clicks: consistency of automatic estimation methods. Journal of the Acoustical Society of America 127, 3239-3247.

Au W.W.L., Kastelein R.A., Benoit-Bird K.J., Cranford T.W. and McKenna M.F. (2006) Acoustic radiation from the head of echolocating harbor porpoises (Phocoena phocoena). Journal of Experimental Biology 209, 2726-2733.

Barnes L.G., Domning D.P. and Ray C.E. (1985) Status of studies on fossil marine mammals. Marine Mammal Science 1, 15-53.

Beedholm K. and Møhl B. (2006) Directionality of sperm whale sonar clicks and its relation to piston radiation theory. Journal of the Acoustical Society of America 119, EL14-EL19.

Behrmann G. and Klima M. (1985) Cartilaginous structures in the forehead of the sperm whale Physeter macrocephalus. Zeitschrift für Säugetierkunde 50, 347-356.

Berta A. and Sumich J.L. (1999) Marine mammals: evolutionary biology. San Diego, CA: Academic Press.

Berzin A.A. (1972) The sperm whale. Jerusalem: Israel Program for Scientific Translations (available from the U.S. Dept. of Commerce, National Technical Information Service, Springfield, VA).

Boenninghaus G. (1903) Der Rachen von Phocaena communis Less. Eine biologische Studie. Zoologische Jahrbücher 17, 1-98.

Britannica Online Encyclopedia (2013) Phytosaur (reptile suborder), available at: http://www.britannica.com/EBchecked/topic/458968/ phytosaur.

Buhl E.H. and Oelschläger H.A. (1986) Ontogenetic development of the nervus terminalis in toothed whales. Evidence for its non-olfactory nature. Anatomy and Embryology 173, 285-294.

Carrier D.R., Deban S.M. and Otterstrom J. (2002) The face that sank the Essex: potential function of the spermaceti organ in aggression. Journal of Experimental Biology 205, 1755-1763.
Clarke M.R. (1970) Function of the spermaceti organ of the sperm whale. Nature 228, 873-874.

Clarke M.R. (1978a) Buoyancy control as a function of the spermaceti organ in the sperm whale. Journal of the Marine Biological Association of the United Kingdom 58, 27-71.

Clarke M.R. (1978b) Structure and proportions of the spermaceti organ in the sperm whale. Journal of the Marine Biological Association of the United Kingdom 58, 1-17.

Clarke M.R. (2003) Production and control of sound by the small sperm whales, Kogia breviceps and K. sima and their implications for other Cetacea. Journal of the Marine Biological Association of the United Kingdom 83, 241-263.

Clifford A.B. and Witmer L.M. (2004) Case studies in novel narial anatomy: 3. Structure and function of the nasal cavity of saiga (Artiodactyla: Bovidae: Saiga tatarica). Journal of Zoology 264, 217-230.

Cranford T.W. (1988) The anatomy of acoustic structures in the spinner dolphin forehead as shown by x-ray computed tomography and computer graphics. In Nachtigall P.E. and Moor P.W.B. (eds) Animal sonar: processes and performance. Nato ASI Series A. New York, NY: Plenum Press, pp. 67-77.

Cranford T.W. (1999) The sperm whale's nose: sexual selection on a grand scale. Marine Mammal Science 15, 1133-1157.

Cranford T.W. (2000) In search of impulse sound sources in odontocetes. In Au W.W.L., Popper A.N. and Fay R.R. (eds) Hearing by whales and dolphins. New York, NY: Springer, pp. 109-155.

Cranford T.W. (2013) Unique Whale Science Images. Welcome to Whale Science, available at: http://www.spermwhale.org/.

Cranford T.W. and Amundin M. (2004) Biosonar pulse production in odontocetes: the state of our knowledge. In Thomas J.A., Moss C.F. and Vater M. (eds) Echolocation in bats and dolphins. Chicago, IL: University of Chicago Press, pp. 27-35.

Cranford T.W., Amundin M. and Norris K.S. (1996) Functional morphology and homology in the odontocete nasal complex: implications for sound generation. Journal of Morphology 228, 223-285.

Cranford T.W., Elsberry W.R., Blackwood D.J., Carr J.A., Kamolnick T., Todd M., Bonn W.G.V., Carder D.A., Ridgway S.H., Bozlinski D.M. and Decker E.C. (2000) Two independent sonar signal generators in the bottlenose dolphin: physiologic evidence and implications. Journal of the Acoustical Society of America 108, 2613-2614.

Cranford T.W., Elsberry W.R., Van Bonn W.G., Jeffress J.A., Chaplin M.S., Blackwood D.J., Carder D.A., Kamolnick T., Todd M.A. and Ridgway S.H. (2011) Observation and analysis of sonar signal generation in the bottlenose dolphin (Tursiops truncatus): evidence for two sonar sources. Journal of Experimental Marine Biology and Ecology $407,81-96$

Curry B.E. (1992) Facial anatomy and potential function of facial structures for sound production in the harbor porpoise (Phocoena phocoena) and Dall's porpoise (Phocoenoides dalli). Canadian Journal of Zoology 70, 2103-2114.

Dubrovsky N., Gladilin A., Møhl B. and Wahlberg M. (2004) Modeling of the dolphin's clicking sound source: the influence of the critical parameters. Acoustical Physics 50, 463-468

Duguy R. (1995a) Kogia breviceps (de Blainville, 1838) - Zwergpottwal. In Robineau D., Duguy R. and Klima M. (eds) Meeressäuger - Wale und Delphine 2. Handbuch der Säuetiere Europas. Wiesbaden: Aula, pp. $598-614$.

Duguy R. (1995b) Kogia simus (Owen, 1866) - Kleinpottwal. In Robineau D., Duguy R. and Klima M. (eds) Meeressäuger - Wale und Delphine 2. Handbuch der Säuetiere Europas. Wiesbaden: Aula, pp. 615-623. 
Ellis R. (1996) The book of whales. New York, NY: Alfred A. Knopf.

Fahlke J.M., Gingerich P.D., Welsh R.C. and Wood A.R. (2011) Cranial asymmetry in Eocene archaeocete whales and the evolution of directional hearing in water. Proceedings of the National Academy of Sciences USA 108, 14545-14548.

Flewellen C.G. and Morris R.J. (1978) Sound velocity measurements on samples from the spermaceti organ of the sperm whale (Physeter catodon). Deep Sea Research 25, 269-277.

Flower W.H. (1867) On the osteology of the cachalot or sperm whale (Physeter macrocephalus). Transactions of the Zoological Society London 6, 309-372.

Fordyce R.E. (2009a) Cetacean evolution. In Perrin W.F., Würsig B. and Thewissen J.G.M. (eds) Encyclopedia of marine mammals. San Diego, CA: Academic Press, pp. 201-207.

Fordyce R.E. (2009b) Cetacean fossil record. In Perrin W.F., Würsig B. and Thewissen J.G.M. (eds) Encyclopedia of marine mammals. San Diego, CA: Academic Press, pp. 207-215.

Fordyce R.E. and de Muizon C. (2001) Evolutionary history of the cetaceans: a review. In Mazin J.M. and de Buffrénil V. (eds) Secondary adaptation of tetrapods to life in water. Munich: Dr Friedrich Pfeil, pp. 169-234.

Frey R., Volodin I. and Volodina E. (2007) A nose that roars: anatomical specializations and behavioural features of rutting male saiga. Journal of Anatomy 211, 717-736.

Gambell R. (1995) Physeter catodon Linnaeus, 1758 - Pottwal. In Robineau D., Duguy R. and Klima M. (eds) Meeressäuger - Wale und Delphine 2. Handbuch der Säuetiere Europas. Wiesbaden: Aula, pp. 625-646.

Geisler J.H., Colbert M.W. and Carew J.L. (2014) A new fossil species supports an early origin for toothed whale echolocation. Nature 508, $383-386$.

Gingerich P.D., ul Haq M., Zalmout I.S., Khan I.H. and Malkani M.S. (2001) Origin of whales from early artiodactyls: hands and feet of eocene Protocetidae from Pakistan. Science 293, 2239-2242.

Goold J.C. (1999) Behavioural and acoustic observations of sperm whales in Scapa Flow, Orkney Islands. Journal of the Marine Biological Association of the United Kingdom 79, 541-550.

Goold J.C., Bennell J.D. and Jones S.E. (1996) Sound velocity measurements in spermaceti oil under the combined influences of temperature and pressure. Deep Sea Research Part I: Oceanographic Research Papers 43, 961-969.

Gordon J.C.D. (1987) Sperm whale groups and social behaviour observed off Sri Lanka. Reports of the International Whaling Commission 37, 205-217.

Heyning J.E. (1989) Comparative facial anatomy of beaked whales (Ziphiidae) and a systematic revision among the families of extant Odontoceti. Contributions in Science 405, 1-64.

Heyning J.E. and Mead J.G. (1990) Evolution of the nasal anatomy of cetaceans. In Thomas J.A. and Kastelein R.A. (eds) Sensory abilities of cetaceans. New York, NY: Plenum Press, pp. 67-79.

Huber E. (1934) Contribution to palaeontology IV: anatomical notes on pinnipedia and cetacea. Publication of the Carnegie Institution Washington 447, 105-136.

Huggenberger S. (2004) Functional morphology, development, and evolution of the upper respiratory tract in toothed whales (Odontoceti) Doctoral dissertation. Department of Biology, Johann Wolfgang Goethe University, Frankfurt am Main, Germany.

Huggenberger S., Ridgway S.H., Oelschläger H.H.A., Kirschenbauer I., Vogl T.J. and Klima M. (2006) Histological analysis of the nasal roof cartilage in a neonate sperm whale (Physeter macrocephalus Mammalia, Odontoceti). Zoologischer Anzeiger 244, 229-238.

Huggenberger S., Rauschmann M.A. and Oelschläger H.H.A. (2008) Functional morphology of the hyolaryngeal complex of the harbor porpoise (Phocoena phocoena): implications for its role in sound production and respiration. Anatomical Record 291, 1262-1270.

Huggenberger S., Rauschmann M.A., Vogl T.J. and Oelschläger H.H.A (2009) Functional morphology of the nasal complex in the harbor porpoise (Phocoena phocoena L.). Anatomical Record 292, 902-920.

Huggenberger S., André M. and Oelschläger H.H.A. (2014) An acoustic valve within the nose of sperm whales Physeter macrocephalus. Mammal Review 44, 81-87.

Jaquet N., Dawson S. and Douglas L. (2001) Vocal behavior of male sperm whales: why do they click? Journal of the Acoustical Society of America 109, 2254-2259.

Kishida T., Kubota S., Shirayama Y. and Fukami H. (2007) The olfactory receptor gene repertoires in secondary-adapted marine vertebrates: evidence for reduction of the functional proportions in cetaceans. Biology Letters 3, 428-430.

Klima M. (1987) Morphogenesis of the nasal structures of the skull in toothed whales (Odontoceti). In Kuhn H.J. and Zeller U. (eds) Morphogenesis of the mammalian skull. Hamburg: Paul Parey, pp. 105-122.

Klima M. (1990) Histologische Untersuchungen an Knorpelstrukturen im Vorderkopf des Pottwals Physeter macrocephalus. Gegenbaurs Morphologisches Jahrbuch 136, 1-16.

Klima M. (1995) Cetacean phylogeny and systematics based on the morphogenesis of the nasal skull. Aquatic Mammals 21, 79-89.

Klima M. (1999) Development of the cetacean nasal skull. Advances in Anatomy, Embryology, and Cell Biology 149, 1-143.

Klima M., Seel M. and Deimer P. (1986a) Die Entwicklung des hochspezialisierten Nasenschädels beim Pottwal (Physeter macrocephalus). Teil I. Gegenbaurs Morphologisches Jahrbuch 132, 245-285.

Klima M., Seel M. and Deimer P. (1986b) Die Entwicklung des hochspezialisierten Nasenschädels beim Pottwal (Physeter macrocephalus). Teil II. Gegenbaurs Morphologisches Jahrbuch 132, 349-374.

Kükenthal W. (1893) Vergleichend-anatomische und entwicklungsgeschichtliche Untersuchungen an Walthieren. Denkschriften der Medicinisch-Naturwissenschftlichen Gesellschaft zu Jena 3, 1-447.

Lawrence B. and Schevill W.E. (1956) The functional anatomy of the delphinid nose. Bulletin of the Museum of Comparative Zoology 114, 103-151.

Lusseau D. (2003) The emergence of cetaceans: phylogenetic analysis of male social behaviour supports the Cetartiodactyla clade. Journal of Evolutionary Biology 16, 531-535.

MacLeod C.D., Reidenberg J.S., Weller M., Santos M.B., Herman J., Goold J. and Pierce G.J. (2007) Breaking symmetry: the marine environment, prey size, and the evolution of asymmetry in cetacean skulls. Anatomical Record 290, 539-545.

Madsen P.T. (2002) Sperm whale sound production. Doctoral dissertation. Department of Biology, University of Aarhus, Aarhus, Denmark.

Madsen P.T. and Surlykke A. (2013) Functional convergence in bat and toothed whale biosonars. Physiology 28, 276-283.

Madsen P.T., Payne R., Kristiansen N.U., Wahlberg M., Kerr I. and Møhl B. (2002a) Sperm whale sound production studied with ultrasound time/depth-recording tags. Journal of Experimental Biology 205, 1899-1906.

Madsen P.T., Wahlberg M. and Møhl B. (2002b) Male sperm whale (Physeter macrocephalus) acoustics in a high-latitude habitat: 
implications for echolocation and communication. Behavioral Ecology and Sociobiology 53, 31-41.

Madsen P.T., Carder D.A., Au W.W.L., Nachtigall P.E., Møhl B. and Ridgway S.H. (2003) Sound production in neonate sperm whales (L). Journal of the Acoustical Society of America 113, 2988-2991.

Madsen P.T., Wisniewska D. and Beedholm K. (2010) Single source sound production and dynamic beam formation in echolocating harbour porpoises (Phocoena phocoena). Journal of Experimental Biology 213, 3105-3110.

Madsen P.T., Lammers M., Wisniewska D. and Beedholm K. (2013) Nasal sound production in echolocating delphinids (Tursiops truncatus and Pseudorca crassidens) is dynamic, but unilateral: clicking on the right side and whistling on the left side. Journal of Experimental Biology 216, 4091-4102.

Malins D.C. and Varanasi U. (1975) The biochemistry of lipids in acoustic tissues. In Malins D.C. and Sargent J.R. (eds) Biochemical and biophysical perspectives in marine biology. New York, NY: Academic Press, pp. 237-290.

Marcoux M., Whitehead H. and Rendell L. (2006) Coda vocalization recorded in breeding areas are almost entirely produced by mature female sperm whales (Physeter macrocephalus). Canadian Journal of Zoology 84, 609-614.

Martin A.R. (1991) Das große Bestimmungsbuch der Wale und Delphine. München: Mosaik.

Mathias D., Thode A., Straley J. and Folkert K. (2009) Relationship between sperm whale (Physeter macrocephalus) click structure and size derived from videocamera images of a depredating whale (sperm whale prey acquisition). Journal of the Acoustical Society of America 125, 3444-3453.

Mazin J.M. (2001) Mesozoic marine reptiles: an overview. In Mazin J.M. and de Buffrénil V. (eds) Secondary adaptation of tetrapods to life in water. Munich: Dr Friedrich Pfeil, pp. 95-117.

Mead J.G. (1972) Anatomy of the external nasal passages and facial complex in the Delphinidae (Mammalia, Cetacea) (cited after Cranford et al., 1996). Doctoral dissertation. Department of Biology, University of Chicago, IL, USA.

Mead J.G. (1975) Anatomy of the external nasal passages and facia complex in the Delphinidae (Mammalia, Cetacea). Smithsonian Contributions to Zoology 207, 1-72.

Mead J.G. and Fordyce R.E. (2009) The therian skull: a lexicon with emphasis on the odontocetes. Smithsonian Contributions to Zoology $627,1-216$

Milinkovitch M.C. (1995) Molecular phylogeny of cetaceans prompt revision of morphological transformations. Trends in Ecology and Evolution 10, 328-334.

Miller G.S. (1923) The telescoping of the cetacean skull. Smithsonian Miscellaneous Collections 76, 1-71.

Møhl B. (2001) Sound transmission in the nose of the sperm whale Physeter catodon. A post mortem study. Journal of Comparative Physiology. A, Sensory, Neural, and Behavioral Physiology 187, $335-340$.

Møhl B., Wahlberg M., Madsen P.T., Miller L.A. and Surlykke A. (2000) Sperm whale clicks: directionality and source level revisited. Journal of the Acoustical Society of America 107, 638-648.

Møhl B., Madsen P.T., Wahlberg M., Au W.W.L., Nachtigall P.E. and Ridgway S.H. (2003a) Sound transmission in the spermaceti complex of a recently expired sperm whale calf. Acoustics Research Letters Online 4, 19-24.
Møhl B., Wahlberg M., Madsen P.T., Heerfordt A. and Lund A. (2003b) The monopulsed nature of sperm whale clicks. Journal of the Acoustical Society of America 114, 1143-1154.

Moris F. (1969) Etude anatomique de la region cephalique du marsouin, Phocaena phocaena L. (Cetacee, Odontocete). Mammalia 33, $666-705$.

Morris R.J. (1986) The acoustic faculty of dolphins. In Bryden M.M. and Harrison R.J. (eds) Research on dolphins. New York, NY: Clarendon Press, pp. 369-399.

Murie J. (1874) On the organization of the caaing whale, Globiocephalus melas. Transactions of the Zoological Society of London 8, 235-301.

Nakamura G., Zenitani R. and Kato H. (2013) Relative skull growth of the sperm whale, Physeter macrocephalus, with a note of sexual dimorphism. Mammal Study 38, 177-186.

Ness A.R. (1967) A measure of asymmetry of the skulls of odontocete whales. Journal of Zoology 153, 209-221.

Nishiwaki M., Ohsumi S. and Maeda Y. (1963) Change of form in the sperm whale accompanied with growth. Scientific Reports of the Whales Research Institute Tokyo 17, 1-17.

Norris K.S. (1980) Peripheral sound processing in odontocetes. In Busne R.G. and Fish J.F. (eds) Animal sonar systems. New York, NY: Plenum Press, pp. 495-509.

Norris K.S. and Harvey G.W. (1972) A theory of the function of the spermaceti organ of the sperm whale (Physeter catodon). In Galler S.R., Schmidt-Koenig K., Jacobs G.J. and Belleville R.E. (eds) Animal orientation and navigation. NASA Special Publication. Washington, DC: Scientific and Technical Information Office, National Aeronautics and Space Administration (NASA), pp. 397-417.

Norris K.S. and Harvey G.W. (1974) Sound transmission in the porpoise head. Journal of the Acoustical Society of America 56, 659-664.

Norris K.S. and Møhl B. (1983) Can odontocetes debilitate prey with sound? American Naturalist 122, 85-104.

Norris K.S., Dormer K.J., Pegg J. and Liese G.J. (1971) The mechanisms of sound production and air recycling in porpoises: a preliminary report. In Proceedings of the 8th Annual Conference on Biological Sonar and Diving Mammals. Menlo Park, CA: Stanford Research Institute.

Oelschläger H.A. (1990) Evolutionary morphology and acoustics in the dolphin skull. In Thomas J.A. and Kastelein R.A. (eds) Sensory abilities of cetaceans: laboratory and field evidence. New York, NY: Plenum Press, pp. 137-162.

Oelschläger H.H.A. (2008) The dolphin brain - a challenge for synthetic neurobiology. Brain Research Bulletin 75, 450-459.

Oelschläger H.A. and Buhl E.H. (1985a) Development and rudimentation of the peripheral olfactory system in the harbor porpoise Phocoena phocoena (Mammalia: Cetacea). Journal of Morphology $184,351-360$.

Oelschläger H.A. and Buhl E.H. (1985b) Occurrence of an olfactory-bulb in the early development of the harbor porpoise (Phocoena phocoena L.). Fortschritte der Zoologie 30, 695-698.

Oelschläger H.H.A. and Kemp B. (1998) Ontogenesis of the sperm whale brain. Journal of Comparative Neurology 399, 210-228.

Oelschläger H.H.A. and Oelschläger J.S. (2002) Brain. In Perrin W.F., Würsig B. and Thewissen J.G.M. (eds) Encyclopedia of marine mammals. San Diego, CA: Academic Press, pp. 133-158.

Oelschläger H.H.A. and Oelschläger J.S. (2009) Brain. In Perrin W.F. Würsig B. and Thewissen J.G.M. (eds) Encyclopedia of marine mammals. San Diego, CA: Academic Press, pp. 134-149. 
Oelschläger H.H.A., Ridgway S.H. and Knauth M. (2010) Cetacean brain evolution: dwarf sperm whale (Kogia sima) and common dolphin (Delphinus delphis) - an investigation with high-resolution 3D MRI. Brain, Behavior and Evolution 75, 33-62.

Oliveira C., Wahlberg M., Johnson M., Miller P.J.O. and Madsen P.T. (2013) The function of male sperm whale slow clicks in a high latitude habitat: communication, echolocation, or prey debilitation? Journal of the Acoustical Society of America 133, 3135-3144.

Papastavrou V., Smith S.C. and Whitehead H. (1989) Diving behaviour of the sperm whale, Physeter macrocephalus, off the Galapagos Islands. Canadian Journal of Zoology 67, 839-846.

Pouchet G. and Beauregard H. (1885) Note sur "l'organe des spermaceti”. Comptes Rendus de la Société de Biologie Paris 8, 342-344.

Price S.A., Bininda-Emonds O.R.P. and Gittleman J.L. (2005) A complete phylogeny of the whales, dolphins and even-toed hoofed mammals (Cetartiodactyla). Biological Reviews of the Cambridge Philosophical Society 80, 445-473.

Purves P.E. and Pilleri G. (1978) The functional anatomy and general biology of Pseudorca crassidens (Owen) with a review of the hydrodynamica and acoustics in Cetacea. In Pilleri G. (ed.) Investigations on Cetacea. Berne: Institute of Brain Anatomy, University of Berne, pp. $67-228$.

Rauschmann M.A. (1992) Morphologie des Kopfes beim Schlanken Delphin Stenella attenuata mit besonderer Berücksichtigung der Hirnnerven. Inaugural-Dissertation. Fachbereich Medizin, Johann Wolfgang Goethe-Universität, Frankfurt am Main, Germany.

Rauschmann M.A., Huggenberger S., Kossatz L.S. and Oelschläger H.H.A. (2006) Head morphology in perinatal dolphins: a window into phylogeny and ontogeny. Journal of Morphology 267, 1295-1315.

Raven H.C. and Gregory W.K. (1933) The spermaceti organ and nasa passages of the sperm whale (Physeter catodon) and other odontocetes. American Museum Novitates 677, 1-17.

Rice D.W. (1998) Marine mammals of the world - systematics and distribution. Lawrence, KS: Allan Press.

Ridgway S.H. and Carder D.A. (2001) Assessing hearing and sound production in cetaceans not available for behavioral audiograms: experiences with sperm, pygmy sperm, and gray whales. Aquatic Mammals 27, 267-276.

Ridgway S.H., Carder D.A. and Green R.F. (1980) Electromyographic and pressure events in the nasolaryngeal system of dolphins during sound production. In Busnel R.G. and Fish J.F. (eds) Animal sonar systems. New York, NY: Plenum Press, pp. 239-249.

Rodionov V.A. and Markov V.I. (1992) Functional anatomy of the nasa system in the bottlenose dolphin. In Thomas J.A., Kastelein R.A. and Supin A.Y. (eds) Marine mammal sensory systems. New York: Plenum Press, pp. $147-177$.

Rommel S.A., Pabst D.A. and McLellan W.A. (2002) Skull anatomy. In Perrin W.F., Würsig B. and Thewissen J.G.M. (eds) Encyclopedia of marine mammals. San Diego, CA: Academic Press, pp. 1103-1117.

Rommel S.A., Pabst D.A. and McLellan W.A. (2009) Skull anatomy. In Perrin W.F., Würsig B. and Thewissen J.G.M. (eds) Encyclopedia of marine mammals. San Diego, CA: Academic Press, pp. 1033-1047.

Scammon C.M. (1874) The marine mammals of the Northwestern Coast of North America. Republication: 1968. New York, NY: Dover Publications, 319 pp. San Francisco, CA: John H. Carmany and Company and G.P. Putnam's Sons.

Schenkkan E.J. and Purves P.E. (1973) The comparative anatomy of the nasal tract and the function of the spermaceti organ in Physeteridae (Mammalia, Odontoceti). Bijdragen tot de Dierkunde 43, 93-112.
Schulz T.M., Whitehead H., Gero S. and Rendell L. (2008) Overlapping and matching of codas in vocal interactions between sperm whales: insights into communication function. Animal Behaviour 76, $1977-1988$.

Schulz T.M., Whitehead H. and Rendell L. (2009) Off-axis effects on the multi-pulse structure of sperm whale coda clicks. Journal of the Acoustical Society of America 125, 1768-1773.

Sibson F. (1848) On the blow-hole of the porpoise. Philosophical Transactions of the Royal Society of London 138, 117-123.

Solntseva G.N. and Rodionov V.A. (2012) Structural and functional organization of sound generation and sound perception organs in dolphins. Acta Zoologica Bulgarica 69, 159-173.

Steffen A. and Steffen W. (2003) Pottwale: Im dunklen Blau des Meeres. Bonn: Heel.

Teloni V., Mark J.P., Patrick M.J.O. and Peter M.T. (2008) Shallow food for deep divers: dynamic foraging behavior of male sperm whales in a high latitude habitat. Journal of Experimental Marine Biology and Ecology 354, 119-131.

Teloni V., Zimmer W.M.X. and Tyack P.L. (2005) Sperm whale trumpet sounds. Bioacoustics 15, 163-174.

Thewissen J.G.M., Williams E.M., Roe L.J. and Hussain S.T. (2001) Skeletons of terrestrial cetaceans and the relationship of whales to artiodactyls. Nature $413,277-281$.

van Beneden P.J. and Gervais P. (1868) Ostéographie des Cétacés Vivants et Fossiles, Comprenant la Description et l'Iconographie du Squelette et du Système Dentaire de ces Animaux: ainsi que des documents relatifs à leur histoire naturelle. Paris: Arthus Bertrand.

Wahlberg M. (2002) The acoustic behaviour of diving sperm whales observed with a hydrophone array. Journal of Experimental Marine Biology and Ecology 281, 53-62.

Wahlberg M., Frantzis A., Alexiadou P., Madsen P.T. and Møhl B. (2005) Click production during breathing in a sperm whale (Physeter macrocephalus). Journal of the Acoustical Society of America 118, 3404-3407.

Watkins W.A. and Schevill W.E. (1977) Sperm whale codas. Journal of the Acoustical Society of America 62, 1485-1490.

Watkins W.A., Moore K.E. and Tyack P.L. (1985) Sperm whale acoustic behaviors in the Southeast Caribbean. Cetology 49, 1-15.

Watwood S.L., Miller P.J.O., Johnson M., Madsen P.T. and Tyack P.L. (2006) Deep-diving foraging behaviour of sperm whales (Physeter macrocephalus). Journal of Animal Ecology 75, 814-825.

Weilgart L. and Whitehead H. (1993) Coda communication by sperm whales (Physeter macrocephalus) off the Galápagos Islands. Canadian Journal of Zoology 71, 744-752.

Weir C.R., Frantzis A., Alexiadou P. and Goold J.C. (2007) The burstpulse nature of sounds emitted by sperm whales (Physeter macrocephalus). Journal of the Marine Biological Association of the United Kingdom 87, 39-46.

Whitehead H. (1996) Babysitting, dive synchrony, and indications of alloparental care in sperm whales. Behavioral Ecology and Sociobiology 38, 237-244.

Whitehead H. (2003) Sperm whales: social evolution in the ocean. Chicago, IL: University of Chicago Press.

Whitehead H. (2009) Sperm whale Physeter macrocephalus. In Perrin W.F., Würsig B. and Thewissen J.G.M. (eds) Encyclopedia of marine mammals. San Diego, CA: Academic Press, pp. 1091-1097.

Whitehead H. and Weilgart L. (2000) The sperm whale: social females and roving males. In Mann J., Connor R.C., Tyack P.L. and 
Whitehead H. (eds) Cetacean societies. Chicago, IL: University of Chicago Press, pp. 154-172.

World Association of Veterinary Anatomists (2012) Nomina Anatomica Veterinaria (NAV). Nomina Anatomica Veterinaria, available at: http://www.wava-amav.org.

Zimmer W.M.X., Madsen P.T., Teloni V., Johnson M.P. and Tyack P.L. (2005a) Off-axis effects on the multipulse structure of sperm whale usual clicks with implications for sound production. Journal of the Acoustical Society of America 118, 3337-3345.

and
Zimmer W.M.X., Tyack P.L., Johnson M.P. and Madsen P.T. (2005b) Three-dimensional beam pattern of regular sperm whale clicks confirms bent-horn hypothesis. Journal of the Acoustical Society of America 117, 1473-1485.

\section{Correspondence should be addressed to:}

S. Huggenberger

Department II of Anatomy, University of Cologne, 50924 Cologne, Germany

email: st.huggenberger@uni-koeln.de 